\title{
UNA CIUDAD DE LOS VASCONES EN EL YACIMIENTO DE CAMPO REAL/FILLERA (SOS DEL REY CATÓLICO-SANGÜESA)
}

\author{
POR
}

JAVIER ANDREU PINTADO

Universidad Nacional de Educación a Distancia - UNED

JAVIER ARMENDÁRIZ MARTIJA

Servicio de Patrimonio Histórico del Gobierno de Navarra

PABLO OZCÁRIZ GIL

Universidad Rey Juan Carlos

\author{
MARÍA GARCÍA-BARBERENA UNZU
}

Gabinete Trama

ÁNGEL A. JORDÁN LORENZO

Archivo Epigráfico de Hispania

\section{RESUMEN}

El presente trabajo aborda el estudio detallado y preliminar del yacimiento arqueológico de Campo Real/Fillera (Sos del Rey Católico/Sangüesa, en el límite entre las actuales provincias de Zaragoza y Navarra) con especial atención a su etapa romana. Se procede a la revisión del material arqueológico y epigráfico procedente del lugar, se defiende la condición de enclave urbano del yacimiento y se plantea una hipótesis respecto de su identificación con las ciudades que las fuentes antiguas atribuyen a los Vascones.

\section{SUMMARY}

The following paper deals with the detailed and preliminary study of the archaeological site of Campo Real/Fillera (Sos del Rey Católico/Sangüesa, between today Zaragoza and Navarra provinces) specially focusing in its Roman period. The paper exposes a review of the archeological and epigraphical material from the site, proposes an urban condition for it and raises some hypothesis on its identification with one of the cities that ancient sources tribued to Vascones.

PALABRAS CLAVE: Poblamiento romano, Vascones, Sos del Rey Católico, Campo Real, Cinco Villas de Aragón, Epigrafía Latina.

KEY WORDS: Roman settlement, Vascones, Sos del Rey Católico, Campo Real, Cinco Villas de Aragón, Latin Epigraphy.

${ }^{*}$ El presente artículo se integra en los trabajos que sobre poblamiento romano en el solar de los Vascones viene desarrollando el Grupo de Estudios Avanzados en Historia Antigua coordinado desde la Universidad Nacional de Educación a Distancia (UNED) y del que forman parte los firmantes del mismo.

\section{INTRODUCCIÓN}

Para quien esté mínimamente versado en la Arqueología navarro-aragonesa, el topónimo Campo Real evoca uno de los conjuntos arqueológicos más referidos en la bibliografía específica, uno de los más interesantes y también uno de los peor conocidos. Desde que a comienzos de los años setenta, A. Marcos Pous y A. Castiella ${ }^{1}$, primero, y M. MartínBueno $^{2}$, después, llamasen la atención de su potencial arqueológico, las noticias sobre el enclave han estado reclamando una revisión del mismo y un replanteamiento de su función en la Antigüedad y más en tan rico entorno arqueológico como el que le rodea: la Valdonsella aragonesa ${ }^{3}$ — de la que forma parte—, el término municipal ya navarro de Sangüesa — con el que el yacimiento limita y sobre parte del cual se extiende $^{4}$ - y la —en lo arqueológico — tremendamen-

\footnotetext{
${ }^{1}$ Marcos Pous y Castiella 1974.

${ }^{2}$ Martín-Bueno 1982, 163-164.

${ }^{3}$ Objeto de estudio arqueológico por Lostal 1984 que ya la había tratado en su conocido trabajo Lostal 1982, 23-26.

${ }^{4}$ Pocas áreas resultan tan extraordinariamente ricas en documentación arqueológica romana como la del término municipal de Sangüesa y los colindantes de Sos del Rey Católico -hacia el Sur-, Cáseda, Gallipienzo y Eslava -hacia el Suroeste-, Aibar -hacia el Oeste- y Lumbier -hacia el Norte- pues prácticamente en todos existen notables evidencias arqueológicas de época romana. Así Sangüesa ofrece un notable elenco de yacimientos romanos (Labeaga 1987, 9193) que dan continuidad a algunos otros muy interesantes y de raigambre indígena (Armendáriz 2004, 216-222); en el
} 


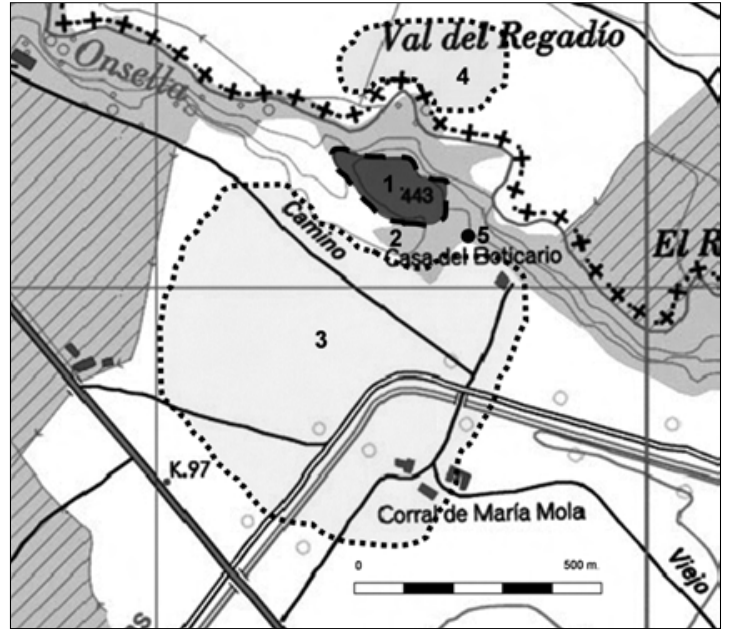

Fig. 1. Mapa topográfico (1:25.000) con indicación del área arqueológica. 1. Oppidum protohistórico; 2. Foso defensivo del citado oppidum de la Edad del Hierro; 3. Área principal de la ciuitas romana en la terraza alta del río Onsella; 4. Área subsidiaria y de territorium de El Regadío, sobre la terraza baja del Onsella; 5. Ruinas de la iglesia románica.

te fértil comarca de las Cinco Villas de Aragón — a la que pertenece jurídicamente el municipio zaragozano de Sos del Rey Católico que acoge la mayor parte del yacimiento- comarca sobre alguno de cuyos yacimientos hemos publicado revisiones de conjunto bien recientes ${ }^{5}$.

El enclave, que también se conoce en la bibliografía como Campo Real/Fillera ${ }^{6}$, ocupa parte central de la llanura abierta entre las últimas estribaciones de la Sierra de la Peña — en la provincia de Zaragoza- - y la Sierra de Leire - ya en Navarra-, llanura surcada de Oeste a Este por el curso del río Onsella y cerrada hacia el Noroeste por el cauce del río Aragón y por las

término municipal de Sos existen importantes conjuntos arqueológicos como el de Sofuentes (Lostal 1982, 78-82) -especialmente conocido por el notable lote de material epigráfico que ha aportado (Escalada 1943, 81-85; Fatás y Martín-Bueno 1977, 31-36 —ERZ, 32-37 y 39-40; IRMN, 61 y 63; HEp 5, 928; y $A E, 1977,483-484-;$ Lostal 1982, 79-82 y Beltrán Lloris 1986(a), 59-60); en el cerro de Santacrís, al Sur del actual municipio navarro de Eslava la empresa Olcairum viene realizando un Plan Director encargado por el Gobierno de Navarra para la valoración del importante enclave romano que ocupó dicho lugar (Mateo, Armendáriz y Sáez de Albéniz 2007, con toda la bibliografía anterior); y, por último, acerca de Lumbier también contamos con recientes noticias de hallazgos arqueológicos de época romana (Ramos 2007, y, a partir de él Ramírez Sádaba 2006, 189-190 y, con todos los datos, Andreu 2006, 212-213).

${ }^{5}$ Andreu y Jordán 2003-2004.

${ }^{6}$ Así, por ejemplo, en algunos de los Diccionarios al uso, como Martín-Bueno 1980, 602; V. V. A. A. 1980, 221, 234 y 239, y muy recientemente Salinas 2006, 196.

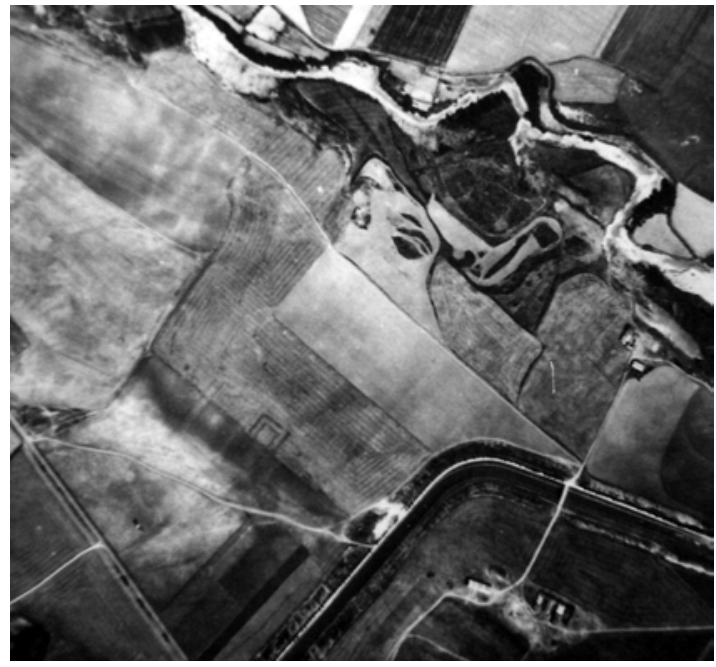

Fig. 2. Fotografía aérea de la Diputación Foral de Navarra (vuelo de 1967).

primeras estribaciones de la citada Sierra de Leire. Se trata, por tanto, de un amplio espolón de terraza atravesado, además, actualmente, por el Canal de Bardenas y por la carretera A-127 que enlaza los municipios de Sos del Rey Católico y de Sangüesa a través de la recoleta aldea de Campo Real. Entre los kilómetros 96 y 97 de dicha vía, y en torno a la Casa del Boticario y al Corral de María Mola - a ambos lados del citado Canal- se concentra la mayor parte del material arqueológico, aunque éste se extiende también por la parcela de El Regadío, al otro lado del Onsella, ya en territorio actualmente navarro (Fig. 1).

Al margen de algunas vagas noticias en la historiografía tradicional ${ }^{7}$ y en trabajos de $\mathrm{J}_{\text {. }}$ Altadill $^{8} \mathrm{o}$

${ }^{7}$ Ceán Bermúdez 1832, 153-154 y 157.

${ }^{8}$ Altadill 1928, 518-519, con noticias de hallazgos numismáticos en los alrededores de Sangüesa que, seguramente (Marcos Pous y Castiella 1974, 111), han de ponerse en relación con el área de Vadoluengo, unos 3 kilómetros al Oeste de Campo Real y que debieron depositarse en alguna institución pública de la capital del país sin que hoy sea posible identificar en cuál de ellas y, por tanto, profundizar en su caracterización. En el transcurso del trabajo del que derivan estas páginas hemos tenido constancia — gracias a información verbal facilitada por diversos vecinos de Sos del Rey Católico- del habitual hallazgo de monedas antiguas en el área objeto de estudio, dato que refrendaría el que aquí comentamos. Más aun, en los mercados y subastas numismáticos circulan habitualmente piezas indígenas y romanas procedentes supuestamente de Campo Real y, en cualquier caso, extraídas del yacimiento de modo irregular. Así, no sólo nos consta el hallazgo de piezas de arsaos o bentian - por ejemplo- sino también de un notable lote de material numismático romano que, por su cantidad, resulta otro indicio no sólo del potencial arqueológico del lugar sino, seguramente también, de su entidad urbana en la Antigüedad, aspecto éste que será oportunamente tratado en estas páginas. 
de A. Balil ${ }^{9}$, el yacimiento fue mencionado en detalle por primera vez por F. Escalada ${ }^{10}$ y - a partir de él- por J. Galiay ${ }^{11}$ que aportaron noticias sobre el hallazgo de material arqueológico al abrirse en los años cincuenta el trazado del Canal de Bardenas que atraviesa el yacimiento en su lado Este ${ }^{12}$. Objeto de una primera prospección por los citados A. Marcos Pous y A. Castiella ${ }^{13}$ a partir de la fotografía aérea del vuelo americano de 1956-57 y de los Trabajos Fotográficos Aéreos de la Diputación Foral de Navarra en 1967 (Fig. 2), tras una revisión del enclave por J. G. Gorges ${ }^{14}$, la mayor parte de la investigación - exceptuando los trabajos de J. C. Labeaga ${ }^{15}$, de

${ }_{9}$ Balil 1960, 188-189, que a partir de Taracena 1949(a), 438, aludirá a un despoblado en las afueras de Sos -tal vez Campo Real, aunque no es seguro (Lostal 1982, 23)- que propondría relacionar con Nemanturissa. Esta reducción Sos del Rey Católico=Nemanturissa será después retomada por Tovar y Blázquez 1975, 353 y dada como probable por Peréx 1986, 180, n. 3 .

${ }^{10}$ Escalada 1943, 88-89. También, a partir de las anotaciones de su cuaderno de campo, en Maruri 2006, 281 donde, respecto de Campo Real/Fillera anota su vinculación a la uia Caesaraugusta-Pompelo, después valorada por Jimeno Jurío 1966, 310 y especialmente por Magallón 1987, 155. No ha resultado muy bien valorada en la bibliografía específica (Martín-Bueno 1980, 177 o Beltrán Lloris 1986(b)) y tampoco, desde luego, goza de muy buena prensa entre los Sosienses la labor del P. Escalada y de la colección arqueológica que aquél fue conformando en el Castillo de Javier y que, más tarde, se incorporaría al Museo de Navarra. Aun conscientes de la importancia que el patrimonio tiene como elemento identitario no queremos dejar pasar la oportunidad que nos brindan estas líneas para, cuando menos, demandar una cierta comprensión y, como consecuencia, una mejor consideración de los trabajos de F. Escalada. Como él mismo relata (Escalada 1943, 70) muchas veces su comprometida mediación salió al paso de graves - aunque inocentesagresiones de los lugareños a determinados objetos arqueológicos recuperados en la época. Si justa nos parece la reivindicación que, tradicionalmente, Aragón ha hecho sobre parte de esos sugerentes materiales que - a través de Javier- hoy se conservan en el Museo de Navarra, justo nos parece también poner en valor el esfuerzo de este sacerdote por transmitir datos fidedignos sobre antigüedades que, de no haber sido por él, a buen seguro se habrían perdido para siempre, y de subrayar el indudable mérito de su trabajo que, sin duda, ha ejercido un considerable y justificado liderazgo en la Arqueología navarra. 227.

${ }^{11}$ Galiay 1946,38 y 70 y a partir de él Uranga 1966, 226-

${ }^{12}$ Sobre el depósito en el Museo de Zaragoza de algunas piezas halladas en dicho contexto puede verse Beltrán Lloris y Paz 2003, 154-155, y Beltrán Lloris 2000, 149.

${ }^{13}$ Marcos Pous y Castiella 1974, 114-117, que constataron elementos arquitectónicos reparovechados en los Corrales del Boticario y de Mola, restos de un capitel corintio, de un canal para conducción de agua y fragmentos de Campaniense A y B, de terra sigillata hispánica, de cerámica común y de cerámica de paredes finas.

${ }^{14}$ Gorges 1976, 352 que lo catalogará como uilla otorgándole una extensión de hasta 9 kilómetros cuadrados (!).

${ }^{15}$ Labeaga 1987, 92, centrados en el área navarra del yacimiento —El Regadío- y en cuyos trabajos quiso ver un
J. Armendáriz ${ }^{16}$ y de la Carta Arqueológica de Aragón ${ }^{17}$ — bien no se ha definido sobre su carácter urbano o rural — como el estudio de parte del material arquitectónico recuperado en la zona firmado por E. Ariño, C. Guiral, M ${ }^{a}$ P. Lanzarote y G. Sopeña ${ }^{18}$ o las anteriores menciones al enclave y a la epigrafía del mismo obra de J. Lostal ${ }^{19}$ — bien lo ha catalogado como una uilla rústica de notables dimensiones ${ }^{20}$.

. Durante los meses de Enero y Mayo de $2008^{21}$ hemos recorrido el área con el objetivo de delimitar su extensión, valorar su posición y dar noticia del material arqueológico que en él se aprecia y de aquél al que - conservado en propiedad particular o bajo la custodia de diversas instituciones públicas - nos ha sido posible acceder. Esta valoración la hacemos conscientes de que transcurridas ya tres décadas de los primeros trabajos las confusas noticias sobre la procedencia y lugar de conservación de gran parte de dicho material y la - a nuestro juicio- escasa importancia otorgada al enclave por la bibliografía precedente justificaban, por sí solas, un replanteamiento de la cuestión precisamente ahora que una

puente de factura romana - sobre el que ha vuelto Zarzuelo 2004, 67- en uno de los estribos arruinados conservados hoy a orillas del Onsella, al Norte de uno de los corrales que ocupa hoy el área central de Campo Real/Fillera, justo bajo la ladera del cerro en el que debió estar el despoblado medieval. En nuestra opinión el citado estribo no ofrece evidencias de una factura romana — sino más bien medieval— por lo que no lo tomaremos en consideración en nuestra valoración del yacimiento. Ello no es óbice para que, efectivamente, debiera haber algún puente o modo de vado del Onsella en época romana al menos para conectar el área urbana de la ciuitas de Campo Real con parte de su notable territorio suburbano que debió extenderse al otro lado de dicho curso fluvial. En cualquier caso, la ostensible acción erosiva del Onsella ha podido arrasar cualquier evidencia en este sentido.

${ }^{16}$ Armendáriz 2004, 222.

${ }^{17}$ Burillo 1989, 107 y 1991, 111.

18 Ariño, Guiral, Lanzarote y Sopeña 1991, 97 y 114.

${ }^{19}$ Lostal 1982, 24 y 25 (y antes en Lostal 1977, 16-17, como veremos), inscripciones después tratadas con más detalle y fotografiadas en Lostal 1984, 22 y 23. Más tarde, las piezas han vuelto a ser citadas, sencillamente, por Beltrán Lloris 1997, 314.

${ }^{20}$ Martín-Bueno 1980, 164; Lostal 1984, 21 o Beltrán Lloris 1986(b), 31-32 o Viladés y Palomar 1997, 272.

${ }^{21}$ Desde estas líneas queremos dejar constancia de nuestra gratitud a Juan Paz, Conservador del Museo de Zaragoza - cerrado por reformas cuando se escriben estas líneasque, ante la imposibilidad de realizar autopsia del material procedente del lugar ha enriquecido el trabajo con interesantes aportaciones, gratitud que queremos hacer extensible, por supuesto, al personal de la Sección de Arqueología del Servicio de Patrimonio Histórico del Gobierno de Navarra, a otras personas e instituciones que serán citadas oportunamente (véase notas 42, 54 y 63), y a los estudiantes Pilar Jiménez, Paula Faus y José Fernández, todos de la UNED, y a la colega Sonsoles Montero, de la Universidad Autónoma de Madrid, que nos acompañaron en algunas de las tareas de revisión del lugar. 
alegación al Plan General de Ordenación Urbana del municipio de Sos del Rey Católico plantea la posible construcción de un complejo urbanístico residencial y recreativo en la zona aunque, al parecer, sin afectar en absoluto al yacimiento arqueológico objeto de estudio en estas páginas ${ }^{22}$ hecho que, desde luego, mucho nos congratula pero que, sin embargo, estamos convencidos ofrece una coyuntura más que apropiada para el replanteamiento del estudio del yacimiento, pendiente desde hace muchos años y para el que aquí sólo pretendemos esbozar las reflexiones que el trabajo sobre el terreno y la autopsia del material procedente del mismo nos han sugerido.

\section{ESTUDIO ARQUEOLÓGICO Y EPIGRÁFICO DEL ENCLAVE}

\section{VALORACIÓN DEL YACIMIENTO}

Como ha podido percibirse desde el comienzo de estas páginas, si de algo creemos estar convencidos es del carácter urbano en la Antigüedad del enclave de Campo Real/Fillera. A favor de dicha realidad hablan diferentes elementos territoriales así como algunos otros de carácter arqueológico que presentaremos más adelante en un apartado específico aunque nos referiremos a ellos —a modo de preámbulo y a la vez de argumento de esta afirmación - también en estas líneas.

En primer lugar, y como ya se anticipó, la zona ofrece las mejores condiciones geoestratégicas para la ubicación de una ciuitas antigua. Así, ocupa una amplia terraza flanqueada por dos cursos fluviales, el río Onsella —al Norte- y el río Aragón —al Oeste- a partir de los cuales poder hacer productivos los alrededores por medio de unos usos del suelo que hay que suponer eminentemente agrícolas ${ }^{23} \mathrm{y}$ de una actividad económica de carácter posiblemente industrial de la que algunos materiales arqueológicos todavía conservados in situ en la zona - especialmente un conjunto de hasta tres prensas de aceite o vino y el contrapeso de una cuarta- son prueba irrefutable.

En segundo lugar, el material arqueológico —especialmente cerámica pero también pequeñas lajas de piedra arenisca que debieron ser empleadas para la

${ }^{22}$ Noticia recogida en Heraldo de Aragón, el 11-1-2008, sobre la que uno de nosotros -J. Andreu- mostró preocupación con sendas Cartas al Director publicadas en Diario de Navarra y en Heraldo de Aragón los días 12 y 13-1-2008. 221 . cubierta de las viviendas en lugar de las usuales tegulae, menos presentes en el lugar- se extiende de manera discontinua por una superficie en ningún caso inferior a las 35 hectáreas lo que, a nuestro juicio, es razón más que suficiente para descartar el seguir manteniendo la identificación del enclave en cuestión con una uilla rústica. A esas aproximadamente 35 hectáreas habría que añadir, las 4,5 que ocupa el antiguo enclave protohistórico, y hasta las 7 que cubrirían, como es lógico, un amplio radio de influencia — por tanto de territorium — del área neurálgica de la supuesta ciuitas y que, desde luego, revelaría la existencia de una amplia serie de unidades menores —uici, pagi y uillae- al servicio del núcleo urbano y de la vertebración económica de su territorio. En esta zona, además del yacimiento navarro de El Regadío — con cerámica romana y un contrapeso de prensa de idéntica filiación cronológica en la primera terraza fluvial del Onsella, ya en el término municipal de Sangüesa- que en su día ya estudiara en detalle el ya citado J. C. Labeaga ${ }^{24}$, a partir del hallazgo de fragmentos de dolia y terra sigillata hemos constatado una segunda unidad de poblamiento menor en el área Sur de Navas Bajas, justo en la cara Norte de una serie de plegamientos terciarios de arenisca que - por las huellas de su explotación- no parece descabellado pensar que fueran empleados como frentes de cantera en época romana al servicio de la arquitectura de la ciuitas de Campo Real extremo que, en cualquier caso, no puede confirmarse. Es plausible pensar, además, que el territorium de la misma se extendiera también hacia la vertiente Oeste - pues está constatado un intenso poblamiento rural romano en el área de Navardún ${ }^{25}$ - y también hacia el Este, por la zona de Mamillas, lugar de hallazgo de miliarios y para la que se cuenta también con evidencias de posibles enclaves rurales romanos ${ }^{26}$.

Sin embargo, con ser importantes estos datos, existen otros más que - a nuestro juicio - parece permiten abundar en el carácter urbano del lugar. Los trabajos recientes de J. Armendáriz y algo anteriores de J. C. Labeaga ${ }^{27}$ han constatado la existencia en la zona de un intenso poblamiento protohistórico del que tal vez el pequeño espolón de terraza que — sobre el Onsella- ocupa la parte central del área de Campo Real/Fillera sea el mejor ejemplo y, en

\footnotetext{
${ }^{24}$ Labeaga 1987, 32-33.

25 Enríquez, Fernández, González y Labeaga 1977, 204206.

${ }^{26}$ Burillo 1992, 110. Para los miliarios puede verse Magallón 1986, 123-141.

27 Armendáriz 2004, 216-220 y Labeaga 1987, 21-49 y 56-67.
} 


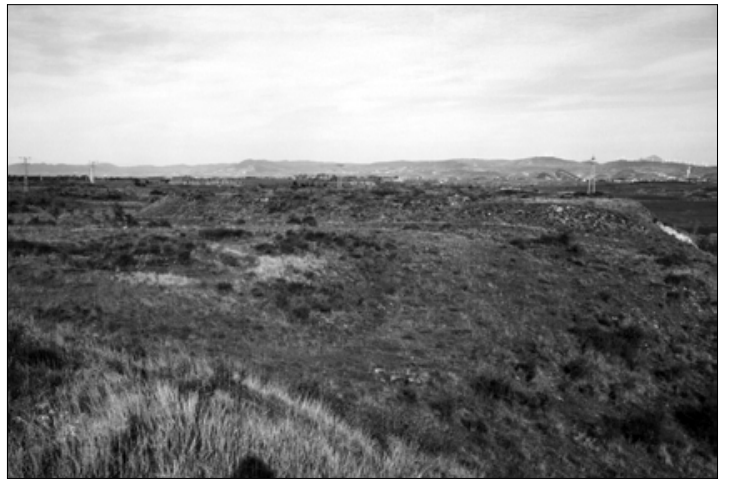

Fig. 3. Imagen del poblado protohistórico de Campo Real/ Fillera con detalle de su foso defensivo, en primer término.

cualquier caso, el más próximo a la ciuitas romana sobre la que aquí reflexionamos. Dotado de un evidente uallum defensivo de entre 40/50 metros de ancho y tal vez 5 de profundidad ${ }^{28}$, el asentamiento ocupó una estratégica posición en el control del curso del Onsella — sobre cuya orilla Sur se erige- y debió ser - tal vez junto al aporte de población de poblados del entorno tales como Puy d'Ull, Los Cascajos, El Castellón, o El Castellar, todos bien conocidos y todos en el término municipal de Sangües $^{29}$ - el antecedente más directo del enclave romano (Fig. 3). De igual modo, en época tardoantigua y altomedieval, la supuesta ciudad debió acabar sus días en la forma de un notable despoblado que

\footnotetext{
${ }^{28}$ Armendáriz 2004, 221.

${ }^{29}$ Sobre ellos puede verse Armendáriz 2004, 216-224. El caso de Los Cascajos ofrece - tal vez- la información más atractiva. Según han constatado los trabajos en superficie de Armendáriz 2004, 216-218, todo parece indicar que éste fue un enclave - a no más de cinco kilómetros en línea recta al Noroeste de Campo Real y seguramente desprovisto de la naturaleza de campamento que se le ha querido otorgar (Labeaga 1987, 21-22) — que debió tener una corta vida a juzgar por la escasa cantidad de material arqueológico que arroja en superficie pese a las evidencias de su perfecta configuración urbanística, que ofrece foso y muralla aún perceptibles, y a los hallazgos - al abrir el camino que lo corta en su cara suroccidental- de monedas de turiasu, sekobirikes, unitkesken o kaiskata, entre otras. Resulta sugerente pensar que — como está constatado sucedió en otras áreas del territorio vascón en los comienzos de la conquista y a lo largo de ella (Armendáriz 2004, 621-625 y Andreu 2004-2005, $285-$ 286) - tal vez la instalación de la ciuitas que proponemos ubicar en Campo Real/Fillera acarreó una profunda transformación de las pautas de ordenación del territorio en la zona provocando - como está constatado más tarde, por ejemplo, para el caso de Pompelo (Armendáriz 2005, 51-54) - el abandono de los antiguos oppida indígenas y el traslado de su población al llano. En cualquier caso, tómese esto sólo como una hipótesis de trabajo pues no puede ser presentada de otra forma ante la acuciante ausencia - por el momentode bases estratigráficas tanto para los oppida referidos como para el propio enclave de Campo Real/Fillera.
}

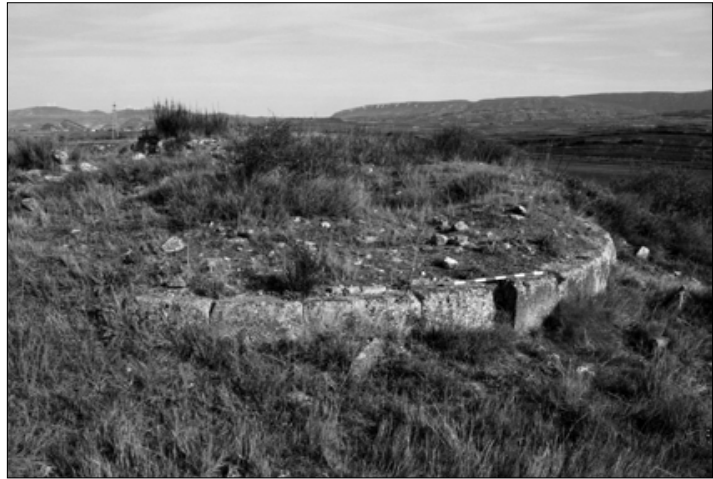

Fig. 4. Restos de la iglesia altomedieval en la parte alta del cerro que preside la llanura de Campo Real/Fillera.

ocupó, precisamente —entre otras áreas-el solar del antiguo oppidum protohistórico y con el que hay que poner en relación el conjunto de piezas medievales que durante años fueron acumulados en la finca de Peña ${ }^{30}$, otras a las que más tarde se aludirá, los restos aún visibles de una pequeña iglesia altomedieval (Fig. 4) y de un posible torreón defensivo, el referido puente sobre el Onsella, las alusiones al lugar - y también a otros próximos- en la documentación medieval $^{31}$ y la sugerente interpretación dada al topónimo Fillera —en relación con algún notable fundus tardoantiguo y ya hispanovisigodo- por G. Fatás y F. Marco ${ }^{32}$. Las muy sugerentes y extraordinarias noticias recientemente aportadas por J. Fernández $z^{33}$ en torno al irregular hallazgo de un soberbio tesorillo de denarios flor de cuño de la ceca de arsaos no demasiado lejos de Campo Real/Fillera -en el área de El Sasillo - no hacen sino constatar la intensidad del poblamiento en la zona ya antes de la continuada presencia romana al margen de alimentar hipótesis de reducción del solar a las comunidades citadas en las fuentes antiguas sobre las que más adelante volveremos aunque sea sólo con carácter provisional.

De igual modo, a este respecto, la excelente ubicación del enclave al pie de la encrucijada de caminos que, desde Iacca - por un lado- y desde Caesaraugusta - por otro- se dirigían hacia Pompelo $^{34}$ y que - posiblemente- pueda tener en el denomi-

\footnotetext{
${ }^{30}$ Martín Bueno 1977, 164.

${ }^{31}$ Moret 1766, 123. Éstas pueden verse comentadas en Labeaga 1987, 32 y 67-68 y, especialmente, en Zarzuelo 2004, 66-68.

${ }^{32}$ V. V. A. A. $1980,160-161$, a partir de Menéndez Pidal 1952, 109, después reproducido y comentado en Escribano y Fatás 2001, 168-170.

${ }^{33}$ Fernández en prensa.

${ }^{34}$ Sobre el trazado de estas dos vías puede verse Armendáriz y Velaza 2006, 139-143.
} 


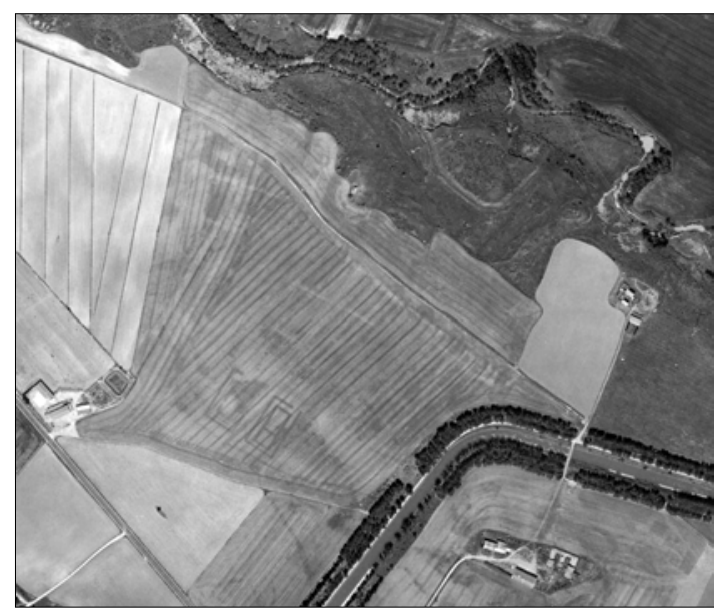

Fig. 5. Fotografía aérea de la zona arqueológica (vuelo del Gobierno de Navarra, en 2008).

nado «Camino Viejo de Sangüesa» —que atraviesa el yacimiento en dirección Oeste/Nordeste- una evidencia de su antiguo trazado no hace sino — además de desaconsejar la interpretación del yacimiento como solar de una villa ${ }^{35}$ - aumentar el valor estratégico del lugar lo que, unido a su extensión, a la amplia secuencia cronológica del material arqueológico que en él se recoge, a la entidad del mismo, e incluso a los datos epigráficos que después serán estudiados son indicios que no deben descartarse respecto de la cuestión que justifica estas líneas.

A este respecto - y conscientes de que, en cualquier caso, la imposibilidad de realizar catas arqueológicas nos obliga a ser extremadamente cautos- la información proporcionada por la fotografía aérea —no sólo la de los vuelos de finales de los años 50 y mediados de los 60 antes referidos sino también la que obra en poder del Servicio de Información Territorial de Navarra (Fig. 5) y hasta la de vuelos previos a la apertura del Canal de Bardenas (Fig. 6) permite apreciar la existencia en la parte central del yacimiento - al Suroeste del actual Corral del Boticario- de - cuando menos- dos grandes y diáfanas estructuras de en torno a 80 metros de largo $\mathrm{x}$ 35 de ancho y que, orientadas hacia el Nordeste, parecen asimismo estar flanqueadas por una serie de tramas de calles más o menos perceptibles a su alrededor - tanto al Norte como al Sur de las mismasque sugieren la existencia de una cierta planificación ortogonal e hipodámica en el lugar (Fig. 7). A espe-

35 Así, por ejemplo, Columella, Rust., 1, 5 desaconseja ubicar las villae al pie mismo de las vías, patrón éste que cuenta con diversos ejemplos en el repertorio hispánico (Fernández Castro 1982, 40-47).

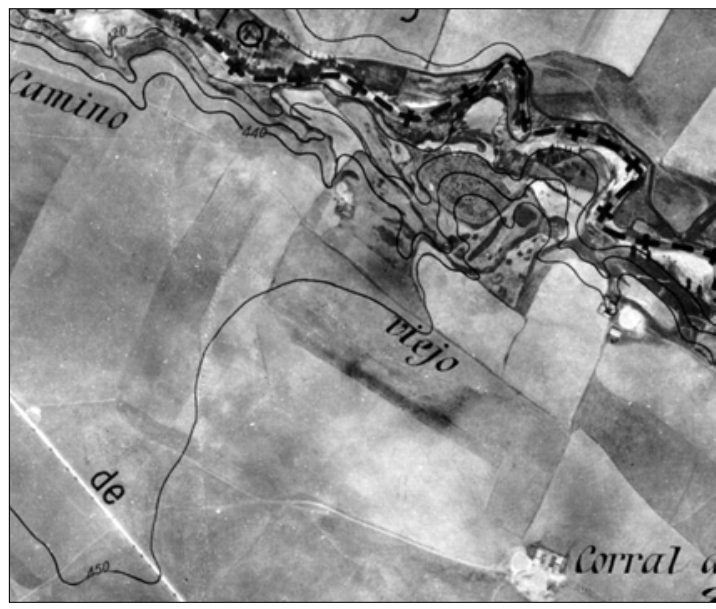

Fig. 6. Fotografía aérea de la zona arqueológica antes de la apertura del Canal de Bardenas (vuelo de la Confederación Hidrográfica del Ebro, en 1927).

ra de que algún día puedan llevarse a cabo actuaciones arqueológicas en la zona, las dimensiones de las huellas de dichas estructuras convierten en atractiva la hipótesis de que en dicho lugar nos encontrásemos ante un área de carácter público dentro de la ciuitas - tal vez varias dependencias abiertas de un espacio porticado multifuncional o, en función del hallazgo de pavimentos de mosaico con motivos marinos en el yacimiento, relacionadas con una edificación termal-, idea ésta que parece encontrar refrendo en el hecho de que las zonas ocupadas por las supuestas estructuras ofrecen, curiosamente, menos material arqueológico en superficie que sus inmediatamente vecinas $^{36}$ lo que permitiría — con prudencia- des-

${ }^{36}$ La historia de la investigación arqueológica ofrece no pocos casos de fiascos y sorpresas a partir del empleo de la técnica de la fotografía aérea (un ejemplo reciente, por el contrario, de la utilidad de la misma puede verse en Ceraudo y Piccarreta 2004 y, para el caso hispano en Navarro, Palao y Magallón 2007, 171-195 y 395-427, con bibliografía). No debe, pues, descartarse que los negativos de edificaciones que, indiscutiblemente, se aprecian en las imágenes aéreas puedan corresponder a alguna corraliza moderna -aunque nos parece que de haber sido así habría una proliferación de negativos de estructuras más notable y no de trazas tan nítidas como el que actualmente se percibe-. La interpretación que aquí se ofrece se plantea sólo como posible hipótesis a partir de la explotación de un indicio más de cuantos ofrece el lugar. De estar dichas estructuras revelando edificaciones romanas latentes es evidente que -por las dimensiones y pese a que la planta parezca aconsejar una interpretación en esa línea- éstas no parecen corresponderse ni con templos (generalmente no mayores de 40 metros de largo: Mierse 1999 y Stamper 2002), ni con insulae (normalmente más pequeñas: V. V. A. A. 1991), ni con basílicas (algo mayores que los templos pero en ningún caso tan amplias: Mar y Ruiz de Arbulo 1987, 37). La opción de un área porticada multifuncional nos parece la más plausible máxime en un enclave que debió centralizar un intenso poblamiento rural como, de he- 


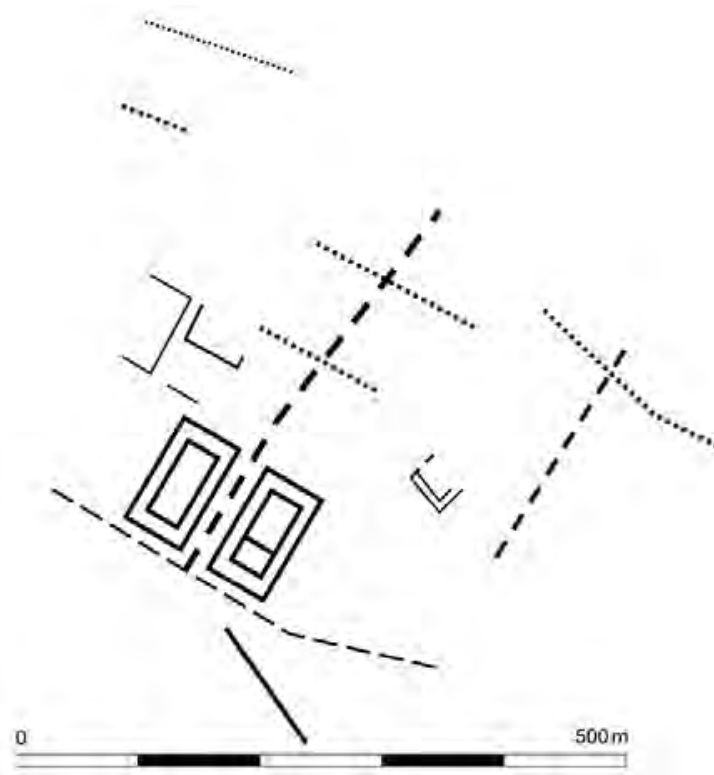

Fig. 7. Dibujo de las estructuras perceptibles en el área arqueológica tras la fotointerpretación de los vuelos de 1927, 1967 y 2008 .

cartar un uso habitacional para las mismas. Tal vez —en este sentido- el notable tamaño de algunos de los sillares que - fruto de las continuadas labores agrícolas - han sido arrojados por los campesinos a las lindes de las fincas que ocupan la zona en cuestión alimentaría la hipótesis funcional propuesta para esta área del yacimiento a espera de ulteriores comprobaciones arqueológicas, de todo punto deseables.

Por último, y como ya en su día sugirieron los estudios de A. Marcos Pous y de A. Castiella ${ }^{37}$, dada la procedencia del área del Corral de Mola —al Sureste del referido Corral de Boticario y, por tanto, del área central de la ciuitas - de al menos dos de las tres inscripciones recogidas en la zona — las dos de carácter funerario-; a juzgar por la concentración de material ornamental a uno y otro lado del Canal de Bardenas —entre éste una tabula ansata anepígrafa

cho, parece sucedió en el vecino enclave de Los Bañales (Beltrán Lloris 1976, 163-164 y Lasuén y Nasarre, en prensa, s. pp.). El ya referido -y en breve comentado en detallehallazgo en el yacimiento de material musivario de época presuntamente altoimperial, de amplias teselas, en blanco y negro y con motivos aparentemente marinos (Fig. 16) invita a no descartar que dichas huellas puedan corresponder a algún tipo de conjunto termal (al respecto, puede verse Nielsen 1990, 68-71, con algunos probables paralelos, que, en cualquier caso, nos limitamos a anotar). Sin embargo, por lo antes advertido, ésta no deja de ser una hipótesis que deberá ser refrendada -o no- con ulteriores datos arqueológicos, si los hubiera.

${ }^{37}$ Marcos Pous y Castiella 1974, 115. sobre placa de arenisca local (Fig. 28), un fragmento de mármol de revestimiento, las cuatro columnas que se guardan en el Museo de Zaragoza (Fig. 8), varios de los capiteles que se custodian en varias colecciones particulares de Sos del Rey Católico, un pequeño tambor de columna aún conservado in situ (Fig. 18), un posible e interesante puluinus con motivos vegetales y relieve antropomorfo ${ }^{38}$ (Fig. 24(a)) en propiedad de una colección de Sos del Rey Católico a la que oportunamente nos referiremos y presumiblemente vinculado a algún altar funerario monumental-y, por último, teniendo en cuenta las aludidas antiguas noticias del P. Escalada sobre el hallazgo de tumbas de incineración ${ }^{39}$ en las obras de construcción del Canal es bien probable que la zona comprendida entre éste y el Corral de Mola pudiera constituir la necrópolis de la ciuitas o, cuando menos, eso invitan a intuir el conjunto de las evidencias arriba constatadas. Es, además, en esa zona - tal vez más alterada y colmatada por la extracción de tierra en las obras de construcción de la citada obra hidráulica-donde, precisamente, decrece notablemente la presencia de material cerámico en superficie y donde el carácter ornamental y suntuario del que aflora - también en las terreras colmatadas a una y otra orilla del Canal - creemos puede alimentar la hipótesis que — con valor de simple posibilidad — aquí planteamos y abundar por tanto en el carácter urbano del yacimiento de Campo Real/Fillera y en su mejor comprensión territorial.

\section{ESTUDIO DEL MATERIAL ARQUEOLÓGICO}

\section{Material Arqueológico}

Como se ha dicho, evidencia clara del potencial arqueológico del área de Campo Real/Fillera es, de forma indiscutible, la calidad del material arqueológico que ha proporcionado el enclave o que aún se conserva in situ, reflejo, por supuesto, además, de la

\footnotetext{
${ }_{38}$ Descrito y dibujado inicialmente por Lostal 1984, 23 , permanece inédito pese a que los trabajos de Gamer 1989, 37-38, NA 23 (lám. 140 e-f) anotaron otro puluinus mucho más modesto procedente de los alrededores Javier y que, en buena lógica, también pudiera guardar relación con Campo Real, sin que esto pueda demostrarse por el momento. Trabajos recientes sobre este tipo de soportes (Beltrán Fortes 2004, 101-110) ofrecen algunos paralelos sugerentes que permiten establecer -como simple hipótesis- la vinculación de la pieza a algún monumental altar funerario (Gamer 1989, 124126) como los que, precisamente, se han descubierto no demasiado lejos de Campo Real, en Santacrís de Eslava (Mateo, Armendáriz y Sáez de Albéniz 2007, 149-155) y que podrían aportar el paralelo geográficamente más cercano.

${ }^{39}$ Escalada 1943, 88-89.
} 


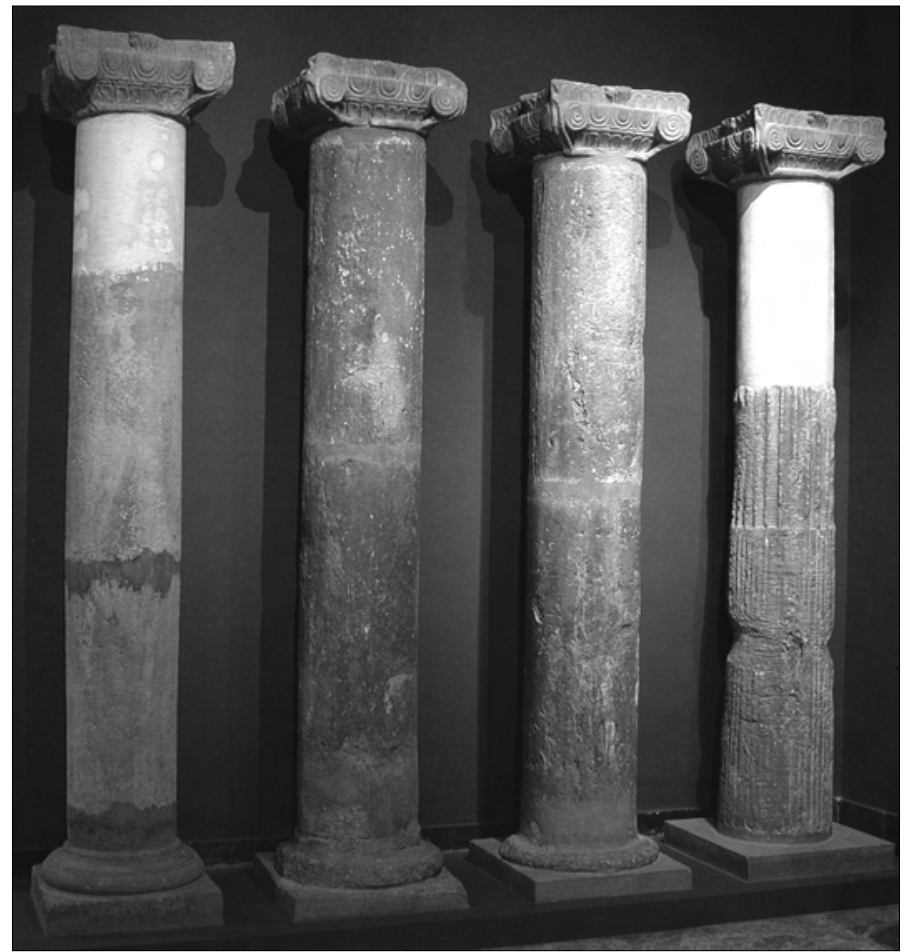

Fig. 8. Columnas jónicas procedentes del área de Canal de Bardenas hoy en el Museo de Zaragoza (Foto: Museo de Zaragoza). casa de Dña. Isabel Rubio ${ }^{42}$ —en la Avenida de Zaragoza, 14, en Sos del Rey Católico- y a otro jónico de volutas y hojas de agua conservado en el patio interior de dicha vivienda (Fig. 9) habiéndose perdido, además, otro corintio exhumado en su día en el área del Corral de Mola. Además, hemos podido estudiar el conjunto - un capitel corintio, uno jónico, un tambor de columna muy dañado y un fragmento de friso ornamental (Fig. 10) - custodiado en dicho municipio zaragozano por Dña. Soledad Vera -Fernando el Católico, 29- propietaria de las fincas anejas al Corral del Boticario en el que ya A. Marcos Pous y A. Castiella constataron la presencia de abundante material arquitectónico reutilizado ${ }^{43}$ e incluso documentaron un hoy perdido capitel corintio $^{44}$. Todavía en la actualidad se conservan in situ en dicho corral hasta dos fragmentos de columna corintia acanalada - empotrada en el ángulo de uno de los muros laterales del patio del citado corral, recientemente remozado- y se aprecian evidencias de al menos dos fustes más de columnas importancia del que ha debido perderse bien por la acción erosiva del Onsella bien por la ya comentada actividad de furtivos y detectoristas.

Un primer apartado en este sentido lo constituye el conjunto de piezas de carácter ornamental o arquitectónico. Un grupo de éstas —el conformado por los capiteles - centró la atención de un excelente trabajo monográfico de E. Ariño, C. Guiral, P. Lanzarote y G. Sopeña que nos eximirá aquí de consideraciones más profundas al respecto ${ }^{40}$. De los diez capiteles que estudiaron estos investigadores -muestra de un estilo marcadamente local que no nos parece deba excluir la vinculación de las piezas a algún conjunto de naturaleza pública - cuatro — todos ellos jónicosse exhibían en la antigua Sala 8 del Museo de Zaragoza (Fig. 8$)^{41}$ y ocho — cuatro jónicos y otros cuatro corintios - se repartían entonces - y todavía hoy- en varias colecciones particulares. En el transcurso de los trabajos de revisión del material que hemos llevado a cabo hemos tenido acceso a uno de los capiteles corintios conservados en el atrio de la

\footnotetext{
40 Ariño, Guiral, Lanzarote y Sopeña 1991, 97-98. Después, algunos de los capiteles han sido tratados por Gutiérrez 1992, 36, 80-81, n's 108, 210 y 217.

${ }^{41}$ Beltrán Lloris y Paz 2003, 19.
}

embutidos en la moderna construcción de la citada edificación (Fig. 11), conjunto que añadir a los tres que — reutilizados - sirven de sostén a la techumbre del corral ubicado al oeste del Corral de Boticario (Fig. 12), al pie del vado que desciende desde Fillera hasta el cauce del Onsella pasando por el estribo

\footnotetext{
42 Vaya desde aquí nuestra gratitud particular a la familia Pérez Gayarre —en especial a Dña. Isabel Rubio-, a Dña. Soledad Vera y a su familia — ambas familias vecinas de Sos del Rey Católico-a Dña. Loli Ibáñez — del Palacio de Sada, en la misma localidad zaragozana-, al personal de la Casa de Cultura del Ayuntamiento de Sangüesa, a los Hermanos Capuchinos de dicha localidad navarra, al personal de la Sección de Arquelogía del Servicio de Patrimonio Histórico del Gobierno de Navarra, a D. Ángel Navallas - de la Asociación Cultural Enrique de Albret de Sangüesa-, al P. Juan C. Labeaga — cronista oficial de dicha localidad navarra - y a otra familia de Sos del Rey Católico - propietaria de un notable lote de material procedente, especialmente, del área del Corral de María Mola y que ha preferido permanecer en el anonimato-, por la amabilidad que nos han dispensado en el transcurso de nuestras investigaciones no sólo permitiéndonos acceder a sus colecciones arqueológicas y epigráficas sino también facilitándonos datos sobre el lugar de procedencia de las piezas en ellas custodiadas y noticias varias sobre el yacimiento objeto de estudio.

${ }^{43}$ Marcos Pous y Castiella 1976, 131-132, Fig. 10.

${ }_{44}$ Marcos Pous y Castiella 1976, 115 y Ariño, Guiral, Lanzarote y Sopeña 1991, 103.
} 

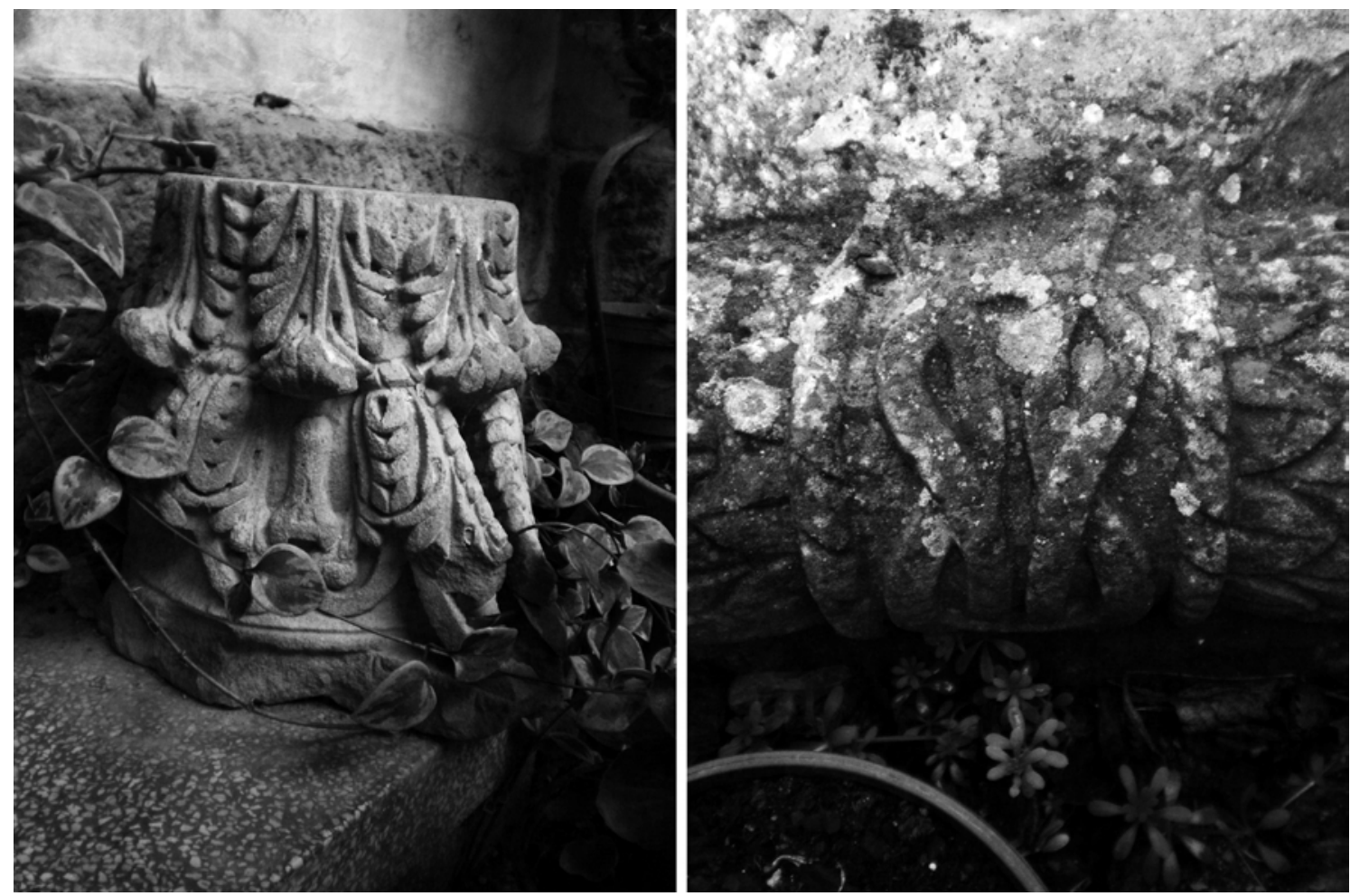

Fig. 9. Capiteles romanos corintio (a) y jónico de volutas y hojas de agua (b) hoy en casa de Dña. Isabel Valero, en Sos del Rey Católico y procedentes del área del Corral de María Mola.

del puente medieval al que aludimos anteriormente. Un notable conjunto de fustes de columna - de hasta cinco ejemplares- procedente del área este del yacimiento se conserva hoy en una colección particular de Sos del Rey Católico (Fig. 13). A los capiteles hasta aquí mencionados hay que añadir uno jónico muy bien conservado y uno aparentemente corintio bastante dañado que - procedentes también del área del Corral de Mola, al este del Canal de Bardenas - se conservan en la misma colección y que en su día fueran - en parte- someramente descritos por J. Lostal ${ }^{45}$ (Fig. 14).

Un segundo conjunto de capiteles romanos - uno jónico de factura idéntica a los conservados en el Museo de Zaragoza (Fig. 8) y otros dos tardoantiguos (Fig. 15) — está hoy repartido por tierras navarras. Se trata de material recogido en su día por el P. Escalada para la colección conformada durante años por los PP. Jesuitas en el Castillo de Javier y después llevada al Museo de $\mathrm{Navarra}^{46}$, conservándose hoy en

\footnotetext{
${ }^{45}$ Lostal 1984, 22.

${ }^{46}$ Así, en los cuadernos de campo de los PP. Escalada y Recondo, recientemente editados (Maruri 2006) hay referencias a «un capitel dórico romano (...) de la Pardina de don
}

el almacén que el Servicio de Patrimonio Histórico del Gobierno de Navarra tiene en Orvina (Pamplo-

Luis Salvo (...), jurisdicción de Sos mugante con Sangüesa» (véase, al respecto, Maruri 2006, 287, $\mathrm{n}^{\circ}$ 140); a «un capitel y una basa romanas traído de cerca de Sos, cedidos por la casa Machín» (Maruri 2006, 337); y, por último, a «un capitel romano de volutas jónicas y sin fuste cedido por la Vda. de Mola en Sos» (Maruri 2006, 337) de los cuales, al menos el primero y el último - por los datos aportados- parece deben ser puestos en relación con el enclave de Campo Real/Fillera. Sin embargo, en nuestro trabajo de revisión del material arqueológico que, procedente de la colección del P. Escalada, se conserva hoy en el Servicio de Arqueología del Gobierno de Navarra no hemos podido localizar la basa romana «cedida por la casa Machín»; el capitel procedente de la finca de dicha familia ha resultado ser de factura ya medieval (Fig. 15(c)); el «capitel dórico romano (...) de la Pardina de don Luis Salvo» no es sino una basa de columna bastante dañada; y el «capitel romano de volutas jónicas (...) cedido por la Vda. de Mola» es, efectivamente, un capitel jónico (Fig. 15(a)) de factura muy semejante a los conservados en el Museo de Zaragoza (Fig. 8). Junto a estos materiales, hemos constatado también - como se ha anotado más arriba - un capitel (Fig. 15(b)) de tipo tardorromano debidamente siglado «Fillera» y que, por el tipo de sigla debió ser recogido no ya por el P. Escalada — que acostumbraba siglar las piezas con números (Maruri 2006, 274)sino por el P. Recondo - que siglaba haciendo notar la procedencia de la pieza en letras negras de buen tamaño- pero del que, en cualquier caso, no hay mención explícita en su cuaderno de campo (Maruri 2006, 318-361). 

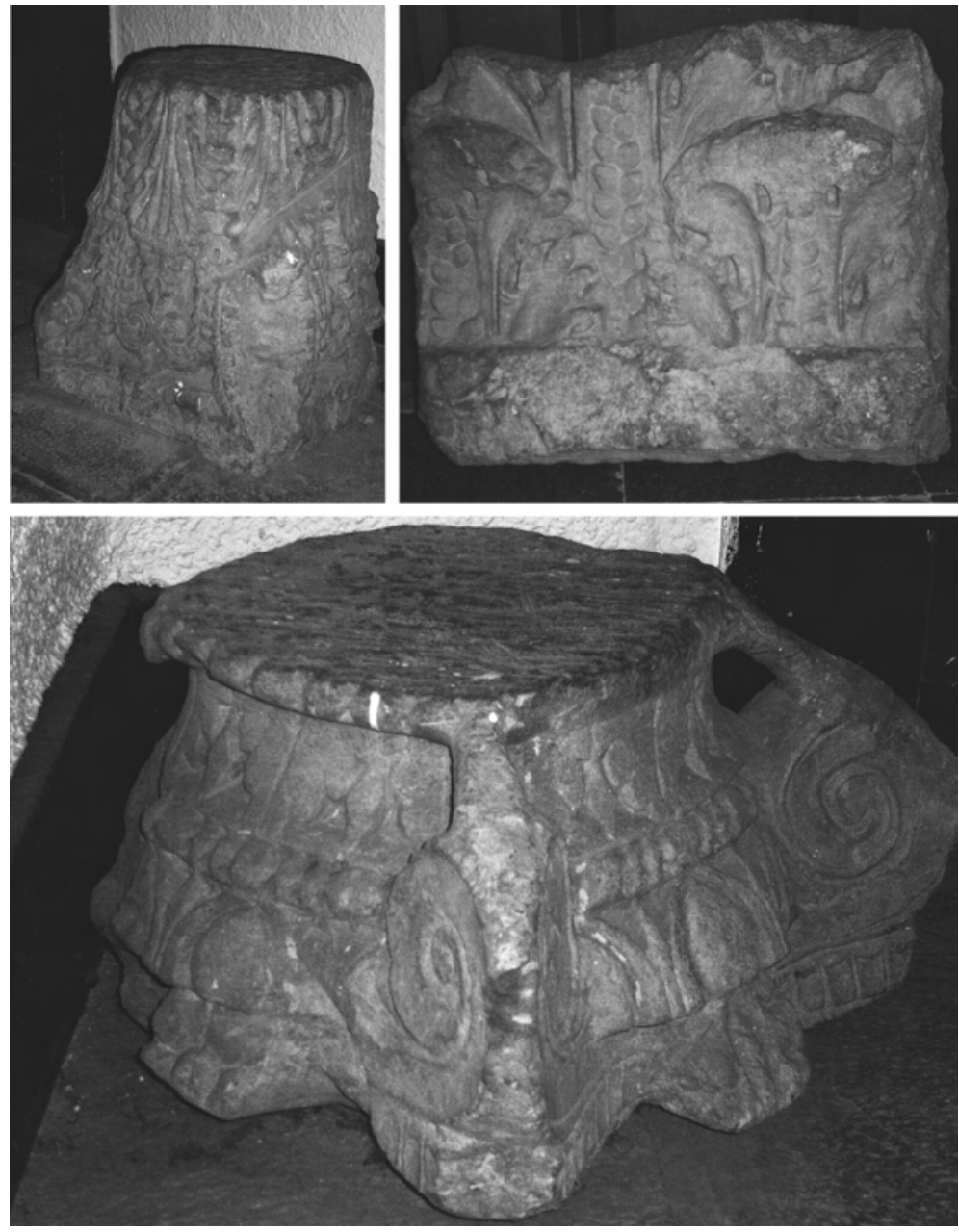

Fig. 10. Colección de material arqueológico de Campo Real -capitel corintio (a), fragmento de friso ornamental (b), y capitel jónico (c)- en propiedad de Dña. Soledad Vera, en Sos del Rey Católico, procedentes del área del Corral del Boticario.

na) y que habrá que añadir a un segundo capitel de factura tardorromana (Fig. 22) que se conserva en una colección particular de Sangüesa sobre la que más adelante volveremos.

Todo este conjunto - que eleva la cantidad de capiteles romanos a doce y que ofrece, de hecho, algunos tipos, como el jónico con tres ovas de la colección de Dña. Soledad Vera (Fig. 10(c)) tal vez de cronología tardo-republicana o augústea ${ }^{47}$ conviviendo con otros con hojas de agua como motivo decorativo, como el jónico custodiado por Dña. Isabel Valero (Fig. 9(b)) ya del siglo in d. C. ${ }^{48}$, y aun con otros de carácter más tardío, como los del Museo de Zarago-

\footnotetext{
${ }^{47}$ Gutiérrez 1988, 111 y 68, con paralelos, y Gutiérrez 1992, 72.

${ }^{48}$ Gutiérrez 1988, 102 y 112, y 1992, 36.
}

za (Fig. 8) — es, sin duda, muestra de la monumentalización del enclave e indicio cierto de la importancia del mismo. Sin embargo, tal vez lo más representativo del material arqueológico recuperado en nuestros trabajos sea el conjunto - hasta ahora inédito salvo escueta referencia de J. A. Lasheras y de D. FernándezGaliano $^{49}$ — de cerca de algo más de veinticinco fragmentos de pavimento musivo en teselas blancas y negras que - procedente del área central del yacimiento, al Oeste del Canal de Bardenas- se guarda hoy en una colección particular del municipio de Sos del Rey Católico junto con los capiteles y columnas arriba constatados (Fig. 16). Sus actuales propietarios han aventurado, incluso, una propuesta de reconstrucción del mismo que permite constatar la presencia de motivos vegetales - al menos una crátera con hojas de palmay animales - tal vez un perro o, más probablemente, un hipocampo - todo ello enmarcado por un doble marco que debía encuadrar toda la escena. Por el tamaño de las teselas, la talla de las figuras en ellas representadas y la presunta amplitud del área cubierta por el pavimento - que espera y merece, desde luego, un ulterior y monográfico estudio - nos parece que dicho mosaico debe ponerse en relación más con un área pública que con una de naturaleza doméstica y, como se ha dicho, tal vez de función termal sin que, en cualquier caso, esto — que había sido supuesto por algunos autores en función de los restos de una conducción hidráulica en piedra documentados por A. Marcos Pous y A. Castiella ${ }^{50}$-, pueda constatarse hasta que no se lleve a cabo el estudio en detalle del

${ }^{49}$ V. V. A. A. 1980, 196-197 y Fernández-Galiano 1987, $37, \mathrm{n}^{\circ} 52$ sin apenas más dato que la constatación de su existencia e incluso, en el primer caso, anotando que en el territorio aragonés «no hay ningún ejemplar figurado» dentro de la modalidad de los mosaicos teselados bícromos.

${ }^{50}$ Ariño, Guiral, Lanzarote y Sopeña 1991, 98, a partir de Marcos Pous y Castiella 1977, 115. 

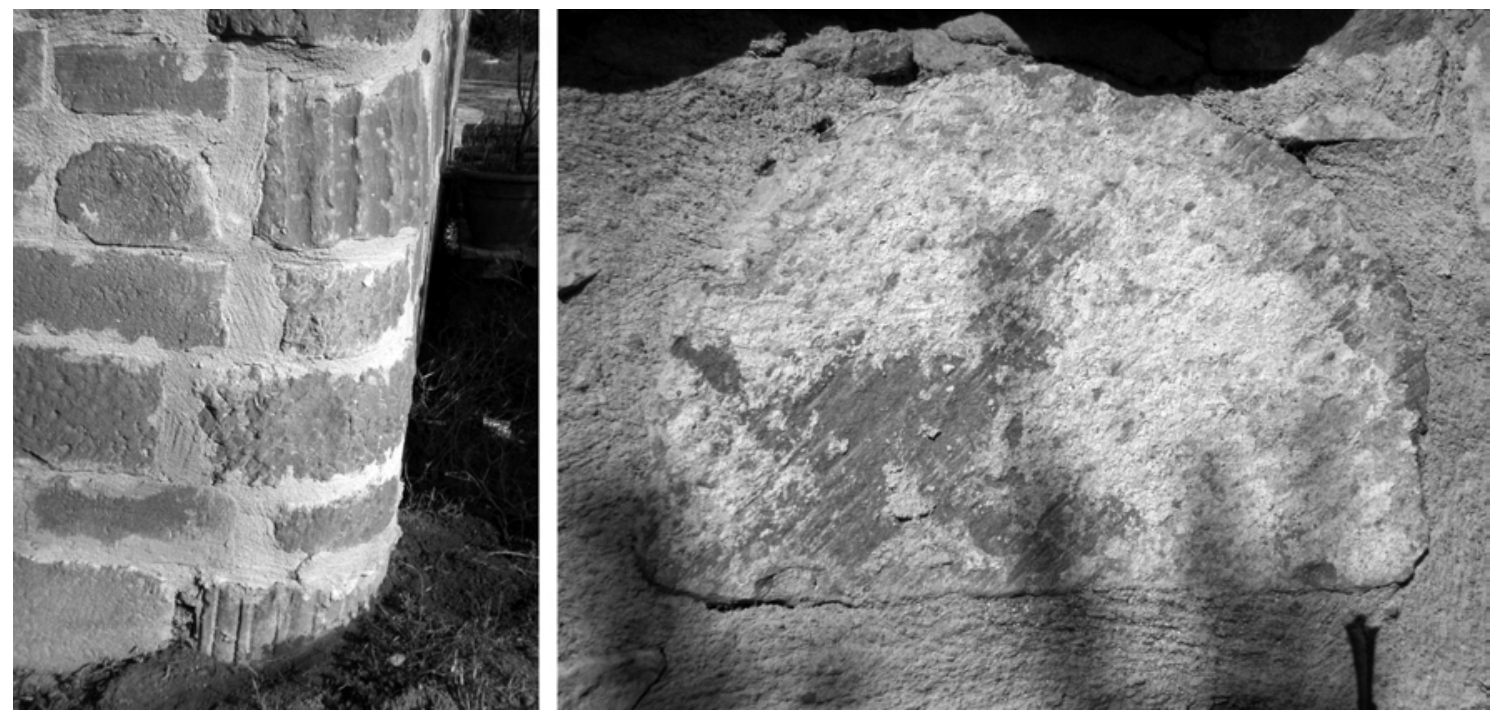

Fig. 11. Detalle de algunos materiales arquitectónicos reutilizados en el Corral del Boticario, en Campo Real/Fillera.

referido pavimento. Paralelos estilísticos y temáticos como los de la C/Curia de Pamplona - hoy en el Museo de Navarra ${ }^{51}$ — así como la técnica del mismo permiten fecharlo no más tarde del siglo II d. C. —si no algo antes- lo que, sin duda, encaja con los datos arqueológicos aportados por la cerámica, y llama la atención, además, del extraordinario desarrollo monumental que la ciuitas de Campo Real/Fillera alcanzó en época alto-imperial.

Conforme a las antiguas noticias de F. Escalada respecto del hallazgo de «capiteles (y) fustes de columnas ${ }^{52} \gg$ al abrir el Canal de Bardenas, todavía en la actualidad se aprecia abundante material ornamental y arquitectónico en las terreras generadas a uno y otro lado de aquél y que hay que añadir al friso arriba mencionado conservado en casa de Dña. Soledad Vera, en Sos del Rey Católico (Fig. 10(b)). Así, y como piezas más representativas - y al margen de numerosos sillares de labra romana, algunos de notables dimensiones, que también se observan al pie del «Camino Viejo de Sangüesa» (Fig. 17)—, pueden citarse un fragmento de cornisa en arenisca moldurada, un pequeño fragmento de tambor de columna igualmente moldurada (Fig. 18), una pieza de mármol rosáceo de revestimiento, algún sillar con guías para el encaje de grapas o de otros sillares, y la tabula ansata anepígrafa que oportunamente será comentada en el estudio del material epigráfico. Como ya se comentó con anterioridad dicha concentración de material unida a los hallaz-

\footnotetext{
${ }^{51}$ Blázquez y Mezquíriz 1985, 55-59, nos 35-38 y Fernández-Galiano $1987,120-121, \mathrm{n}^{\circ} \mathrm{s}$ 191-192.

${ }^{52}$ Escalada 1943, 169.
}

gos de varios epitafios en la zona remiten a la posible presencia de la necrópolis de la ciuitas en el área o, al menos, eso nos parece puede intuirse con bases verosímiles a la luz de dichos hallazgos.

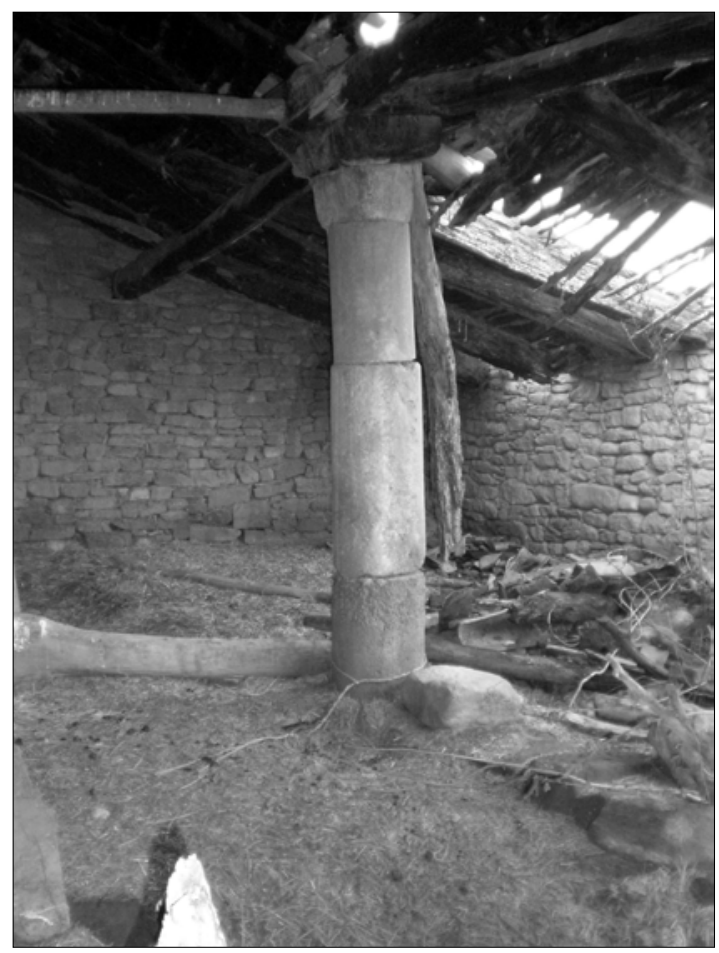

Fig. 12. Tambores de columna y capitel liso reutilizados en un corral del área central del yacimiento de Campo Real/ Fillera. 

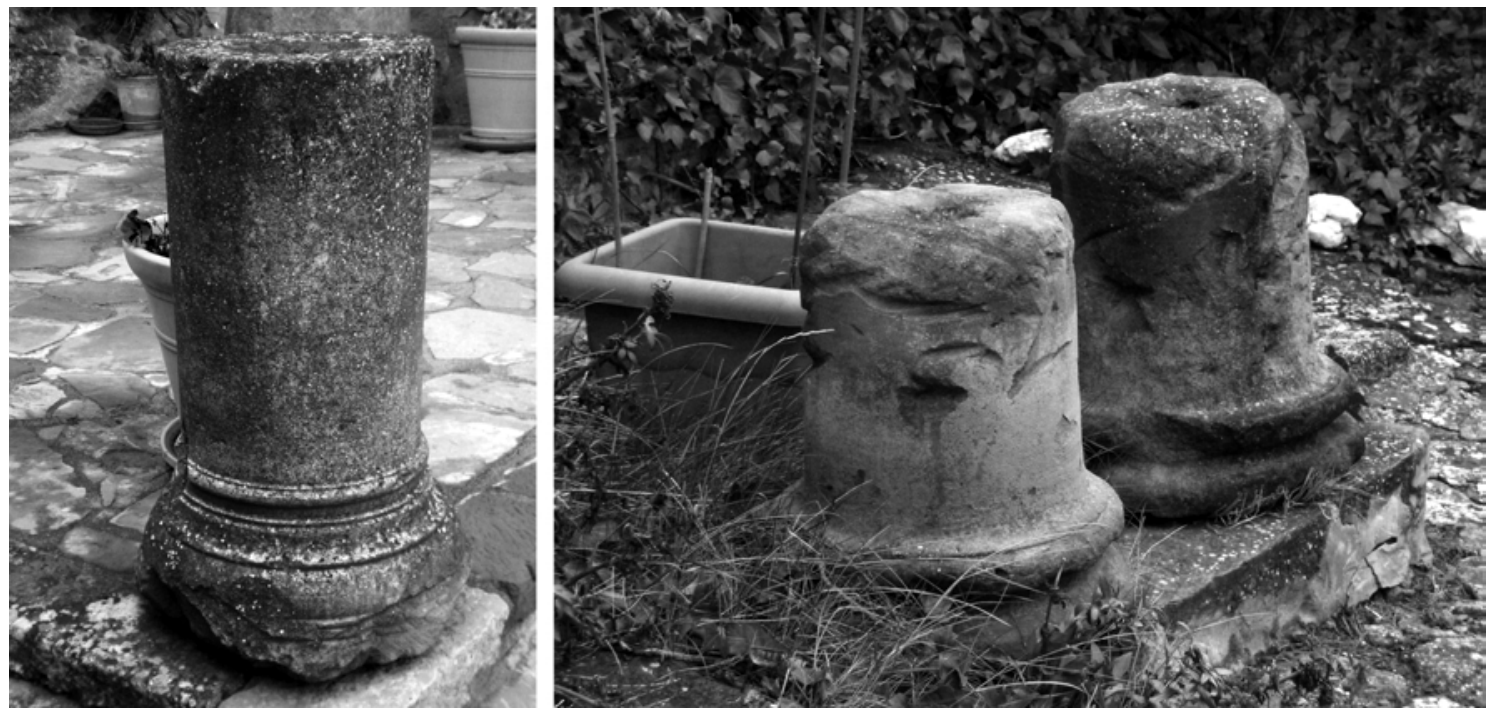

Fig. 13. Detalle de tres de las cinco columnas romanas conservadas en una colección particular de Sos del Rey Católico y procedentes del área Este del Canal de Bardenas.
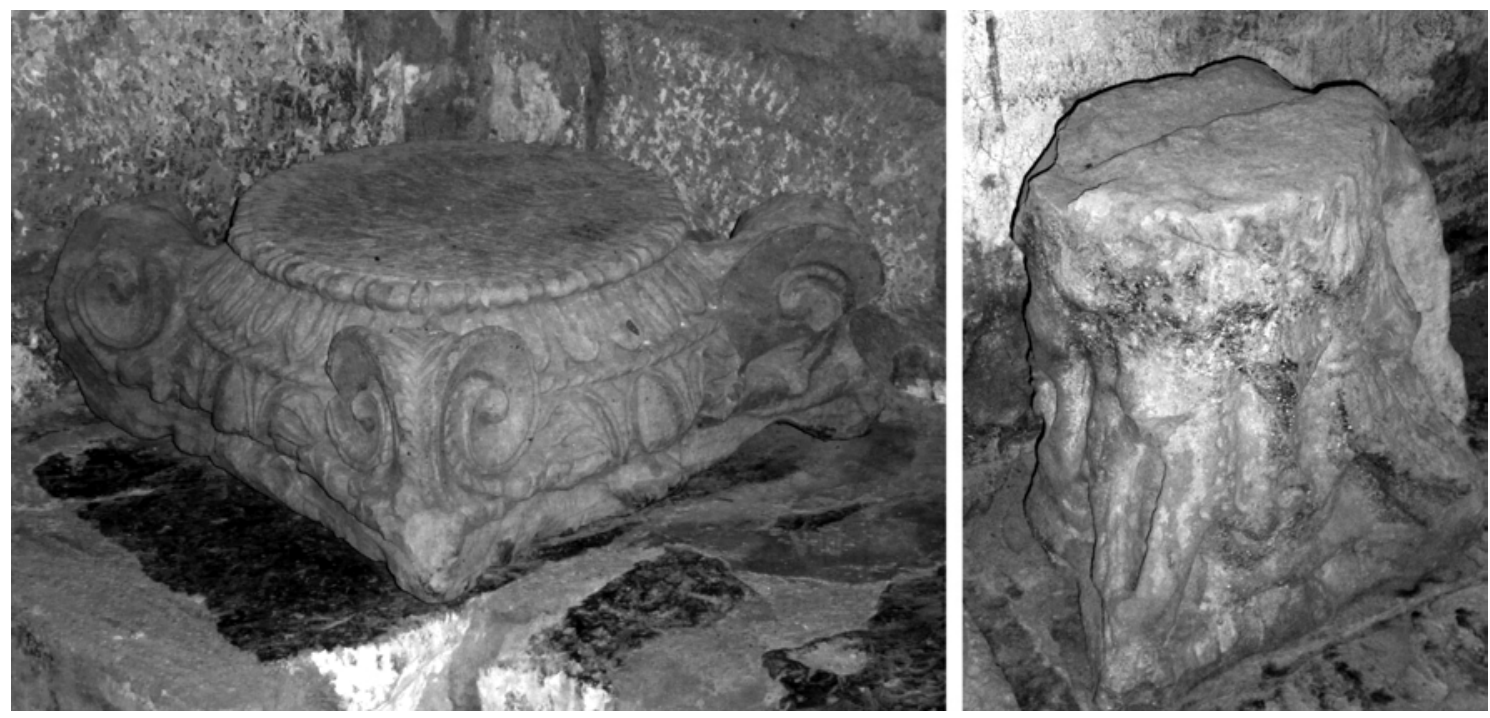

Fig. 14. Capitel jónico (a) y corintio (b) procedente del Corral de María Mola, hoy en una colección particular de Sos del Rey Católico.

A nuestro juicio - porque nos permite constatar algunos aspectos de la vida económica del enclaveresulta especialmente interesante el hallazgo —en otro orden de cosas- de hasta un total de cuatro torcularia de aceite o de vino de los que apenas había dado cuenta hasta ahora la investigación ${ }^{53}$. De tres de ellos

${ }^{53}$ La reciente edición de los cuadernos de los PP. Escalada y Recondo (Maruri 2006) ha permitido constatar que aquél, en Febrero de 1954 vio «una piedra muy curiosa y extraña, con mucha cerámica sigilada... ¿una prensa de acei- se ha conservado la parte central de la prensa -el contrapeso- - y del cuarto una de las dos semiesferas de piedra - las orbes - que permitían que girase todo el conjunto. Los primeros se conservan todavía in situ en el área central del Corral del Boticario y al pie del camino que, a unos 100 metros al este del Canal de Bardenas, separa varias de las parcelas

te?» (Maruri 2006, 323) que, presumiblemente, puede obedecer a algunas de las que aquí se comentan o a otra tal vez ya perdida o reutilizada. 

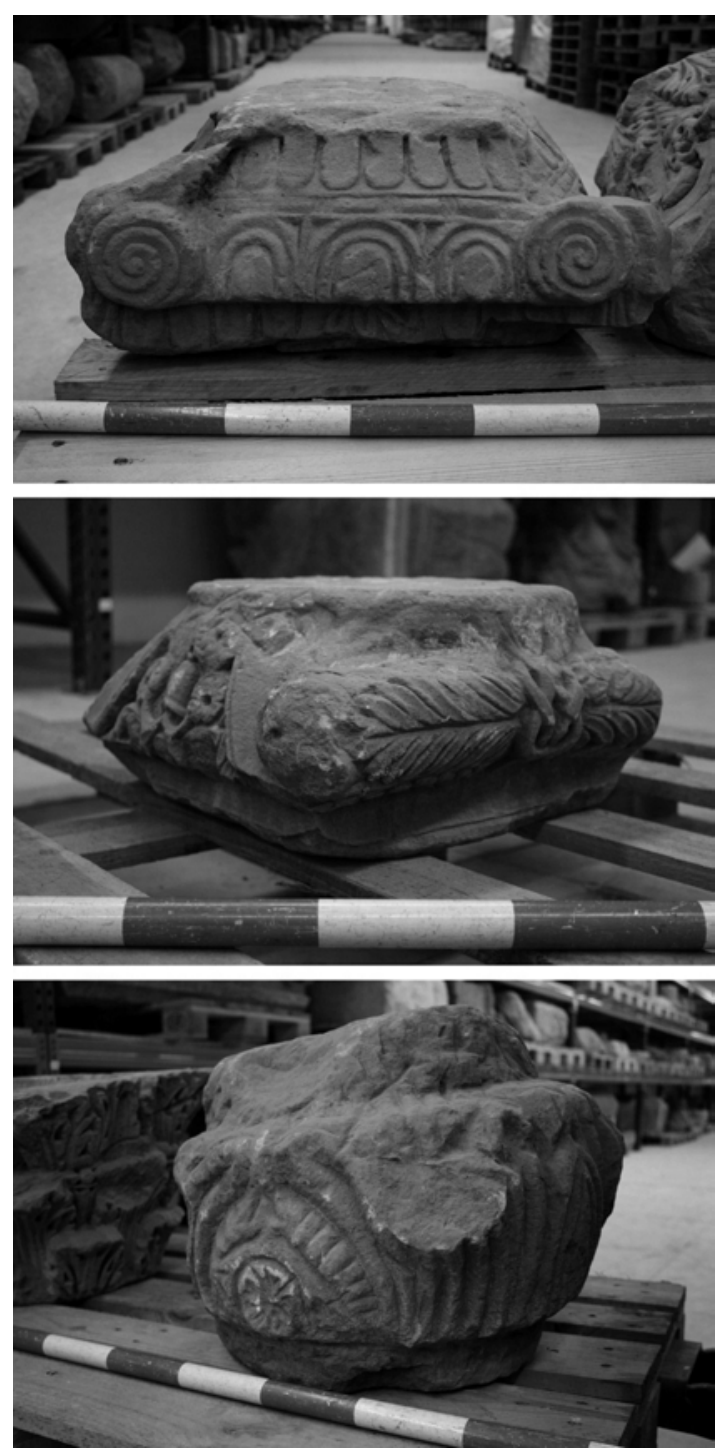

Fig. 15. Capitel jónico (a), tardoantiguo (b) y medieval (c) recuperados en su día por los PP. Jesuitas de Javier y hoy en el Depósito Arqueológico del Gobierno de Navarra, en Orvina (Pamplona).

del área oriental del yacimiento (Fig. 19), cerca del Corral de María Mola, al pie del camino que desde la carretera A-127 se dirige hacia dicho complejo. El primero de ellos — sin duda el más monumental y el mejor conservado (Fig. 19(b)) - exhibe perfectamente las evidencias de las ranuras sobre las que discurrían las vigas de madera con que se ponía en marcha la prensa $^{54}$. La pieza central de un cuarto torcularium ha

${ }^{54}$ Se trataría de una prensa de líquidos del tipo 12 de Brun 1986. Agradecemos a Yolanda Peña, de la Universidad Autónoma de Madrid, la colaboración prestada en la identificación y valoración de estas piezas.
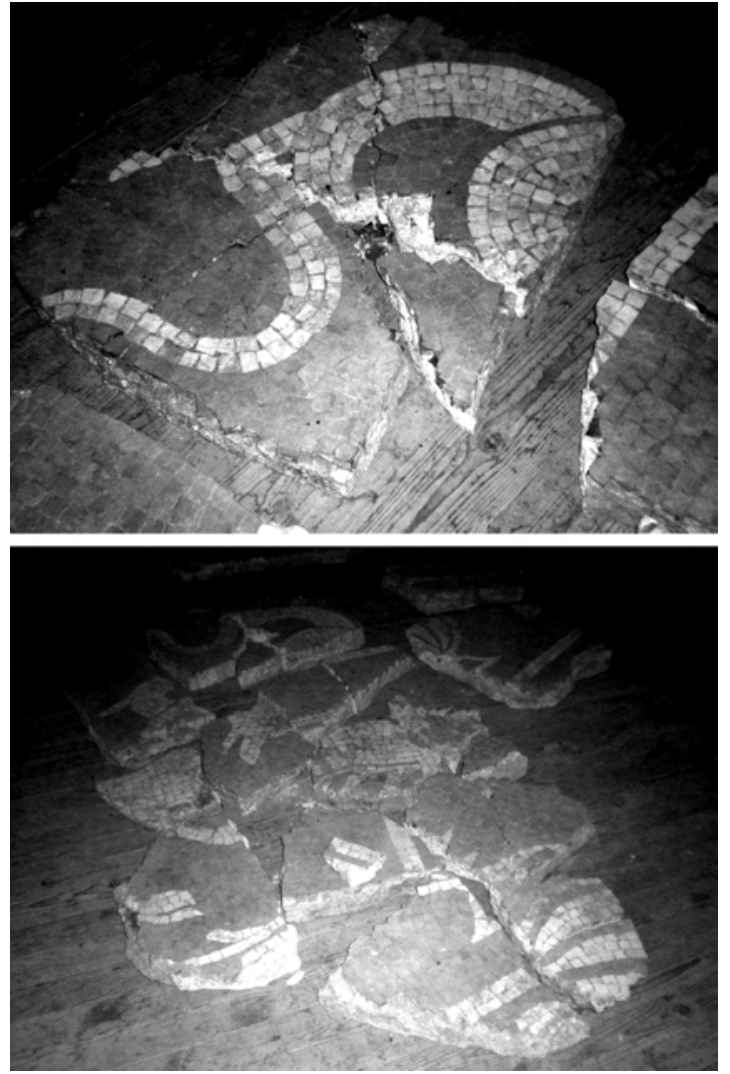

Fig. 16. Fragmentos de pavimento musivo (b) y detalle del mismo (a) procedentes del área central del yacimiento y hoy en propiedad particular en Sos del Rey Católico.

sido documentada en el yacimiento de El Regadío, ya antes comentado (Fig. 20). A este interesante conjunto de hallazgos de naturaleza económica habría que añadir el de una rueda de molino fragmentada recuperada en el área central del yacimiento en el contexto de los trabajos de revisión del enclave de los que dan cuenta estas líneas y que habría que enlazar con las noticias de piezas semejantes transmitidas por el P. Escalada ${ }^{55}$ y ya antes aludidas.

En relación al material cerámico, poco puede añadirse respecto de los datos que, sobre la cuestión, arrojaron en su día las prospecciones sistemáticas de A. Marcos Pous y de A. Castiella ${ }^{56}$ - cuyos resultados fueron debidamente cartografiados, por tipos, en el Atlas de Prehistoria y Arqueología Aragonesas ${ }^{57}$

${ }^{55}$ Escalada 1943, 89.

${ }^{56}$ Marcos Pous y Castiella 1974, 117 y 135.

${ }^{57}$ V. V. A. A. 1981, 220-223 (para fragmentos de Campaniense), 234-238 (para los de sigillata hispánica), 238-241 (para la cerámica común) y 250-253 (para la cerámica de paredes finas) 


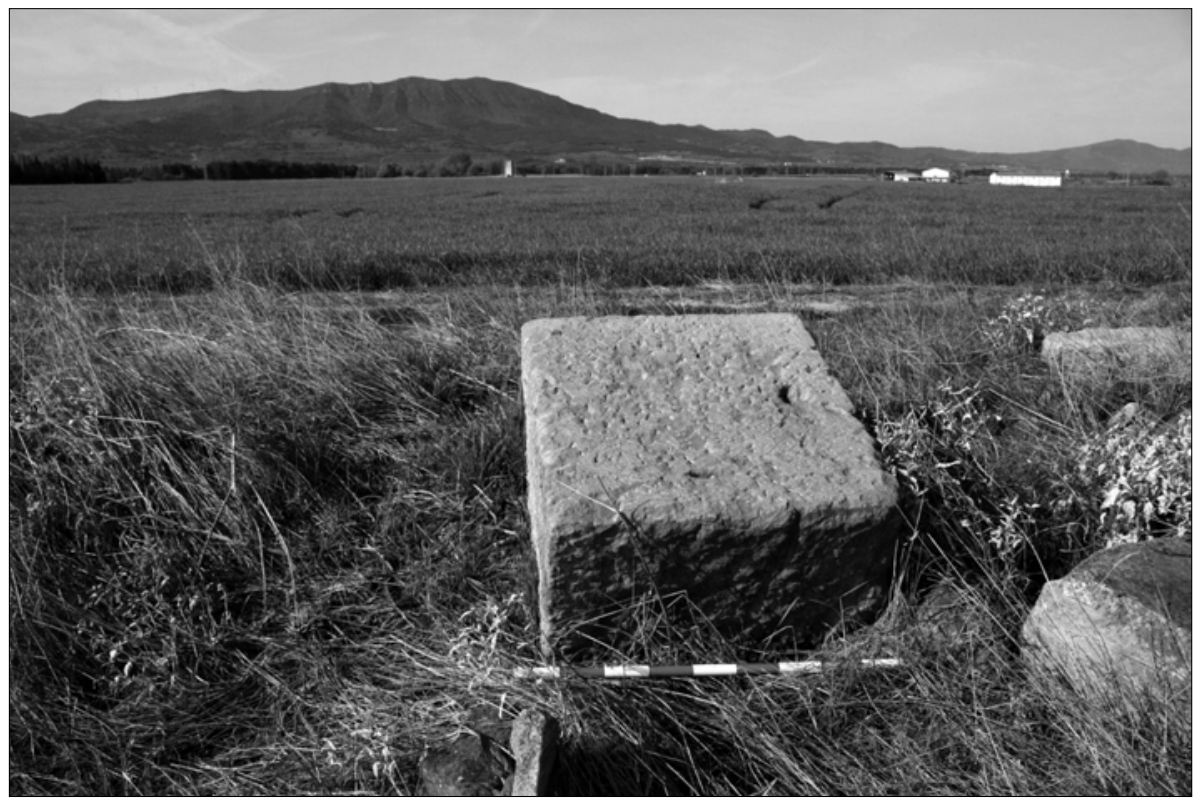

Fig. 17. Monumental sillar de arenisca local conservado in situ al pie del «Camino Viejo de Sangüesa», en el área central de Campo Real/Fillera.
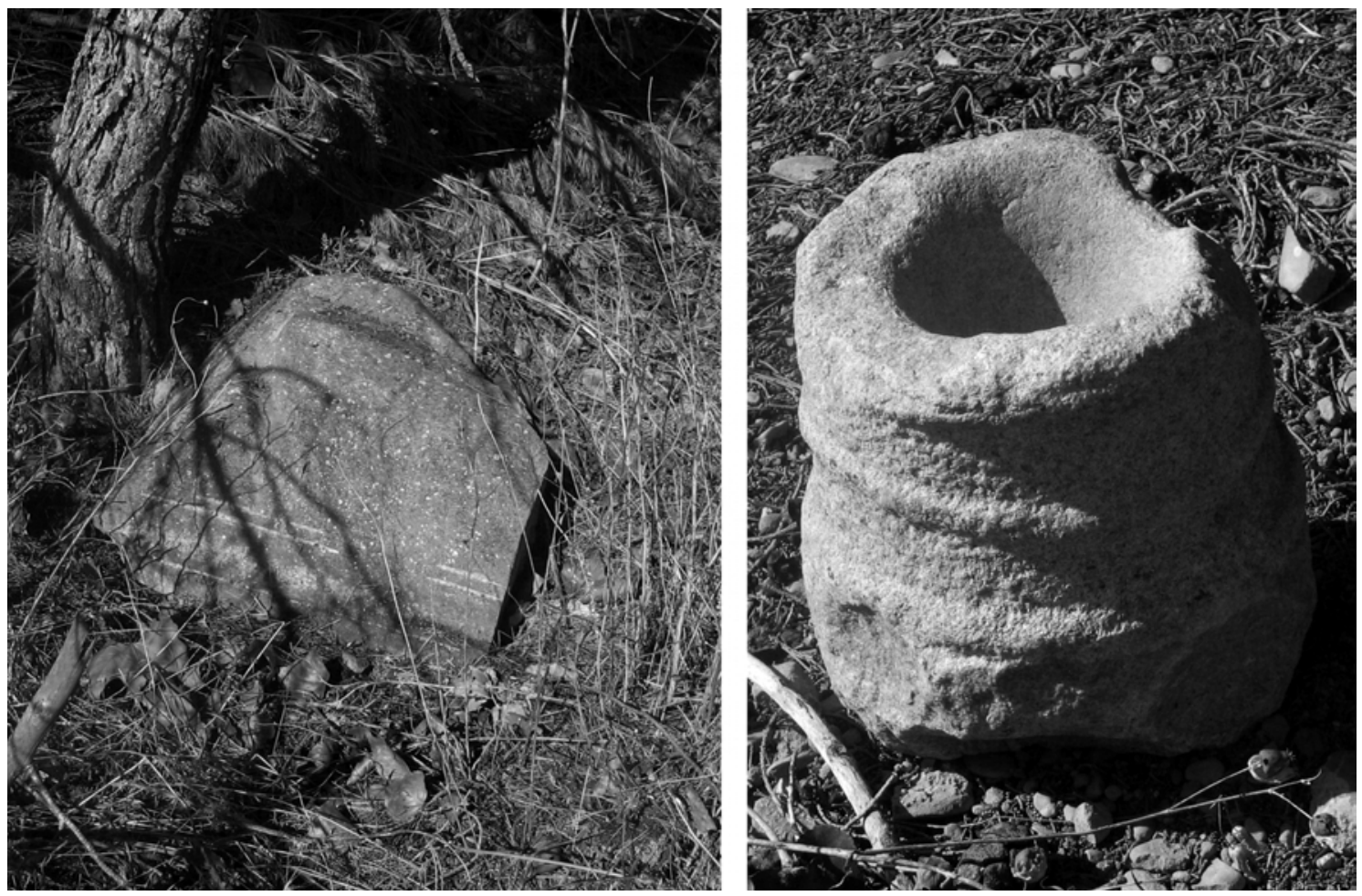

Fig. 18. Diversos materiales arquitectónicos conservados in situ en el lado Este del Canal de Bardenas, junto al Corral de Mola: cornisa (a) y pequeña columna moldurada (b). 

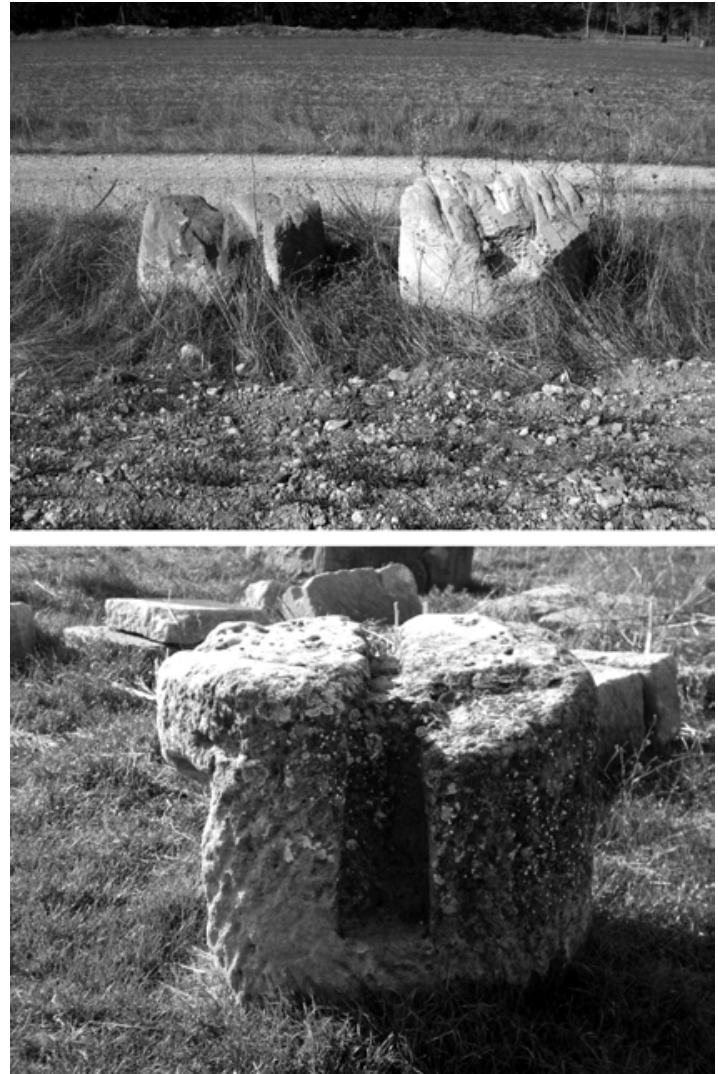

Fig. 19. Dos prensas de líquidos romanas al pie del camino que conduce al área del Corral de Mola (a) y en el área central del Corral del Boticario (b).

y las más recientes —ya en el área de de El Regadío- del aludido J. C. Labeaga ${ }^{58}$. Acaso la constatación de que, efectivamente, además de la sigillata hispánica se aprecian en superficie fragmentos de sigillata itálica y de gálica que permiten aportar más datos al supuesto floruit del enclave en época altoimperial romana, perfectamente refrendado por parte del material arqueológico arriba analizado. Es en dicho momento $-\mathrm{y}$ al menos hasta finales del siglo II d.C., época en la que habría que fechar la moneda de Adriano hallada en Campo Real/Fillera por J. C. Labeaga ${ }^{59}$ - en el que, por otra parte, está constatado que debieron experimentar un notable desarrollo no sólo los enclaves vecinos de la comarca de las Cinco Villas de Aragón - especialmente el yacimiento de Los Bañales ${ }^{60}$, por citar el caso mejor co-

\footnotetext{
${ }^{58}$ Labeaga 1987, 33-37.

${ }^{59}$ Labeaga $1987,36$.

${ }^{60}$ Andreu 2004-2005, 287-288 y Nasarre y Lasuén en prensa, s. pp.
}

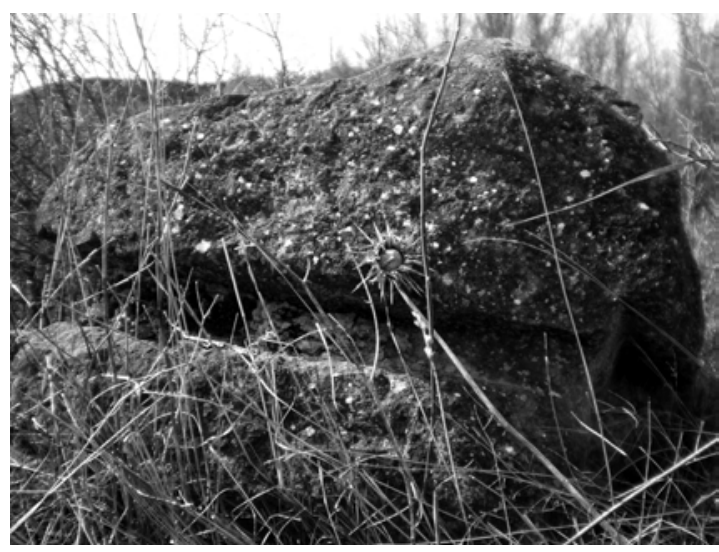

Fig. 20. Contrapeso de prensa de viga conservado in situ en el área de El Regadío, ya en territorio navarro.

nocido- sino también otros igualmente próximos como el de Santacrís de Eslava -aún en el valle del río Aragón-que ve cómo se levanta su monumental necrópolis en el último cuarto del siglo II d. C. ${ }^{61}$, por ejemplo. Por su parte, la presencia de un buen número de fragmentos de dolia en los yacimientos menores ubicados al otro lado del río Onsella encaja perfectamente con el panorama típico del poblamiento de los territoria urbanos en época romana.

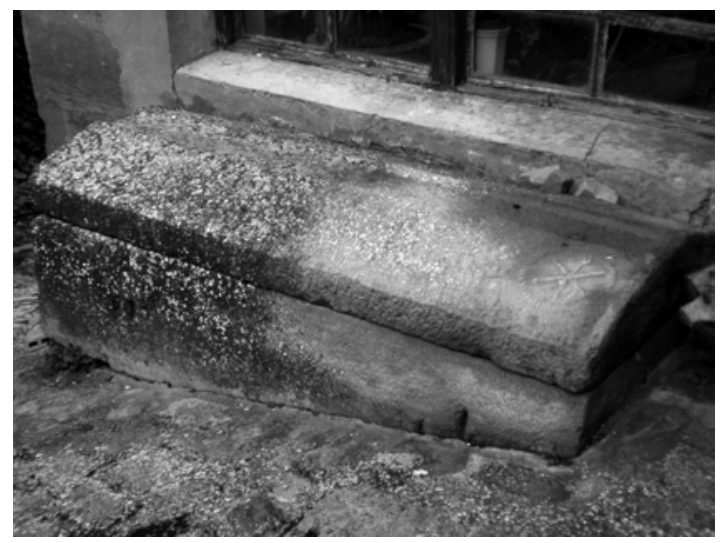

Fig. 21. Uno de los dos sarcófagos hispanovisigodos procedentes de Campo Real/Fillera y hoy en propiedad particular en Sos del Rey Católico. A la derecha se aprecia un Crismón.

Aunque tal vez exceda los objetivos del presente trabajo - centrado en la fase romana del yacimiento estudiado- sí queremos llamar la atención del extraordinario lote del material tardoantiguo y medieval procedente del enclave y que es, sin duda,

\footnotetext{
${ }^{61}$ Mateo, Armendáriz y Sáez de Albéniz 2007, 155.
} 

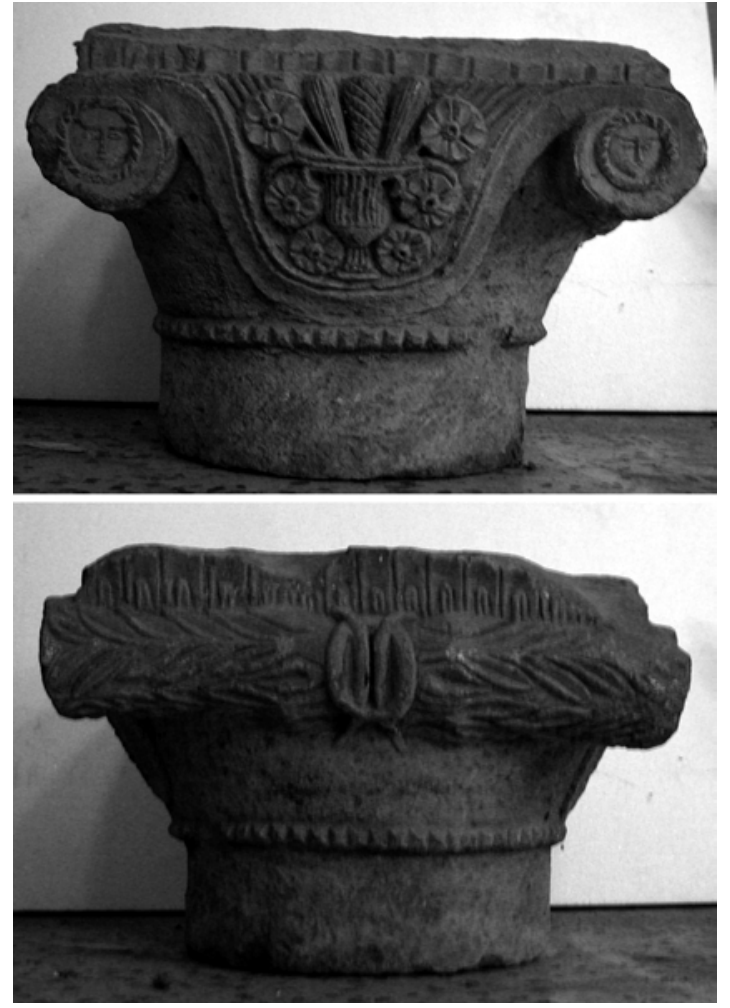

Fig. 22. Capitel tardorromano procedente de Fillera y hoy conservado en propiedad de D. Ángel Navallas, en Sangüesa (Foto: Á. Navallas).

muestra clara del potencial de dicho horizonte cronológico. Así, y además de dos monumentales sarcófagos de piedra arenisca con tapa a doble vertiente conservados en una colección particular —uno de ellos decorado con un Crismón (Fig. 21) y recientemente estudiado ${ }^{62}$ - hemos constatado la presencia de un capitel que, hallado por J. C. Labeaga —que amablemente nos informó de su existencia- se conserva hoy en la vivienda de D. Ángel Navallas, en Sangüesa. Se trata de una pieza profusamente decorada - y con motivos muy parecidos a los de un capitel de Castiliscar lo que permite suponer un cierto arraigo de dicha tipología en la zona $^{63}$ - pero no exenta de motivos de inspiración romana (Fig. 22) como, de hecho, sucede también con los referidos sar-

\footnotetext{
${ }^{62}$ Escribano y Fatás 2001, 153 y 165.

${ }^{63}$ Ariño, Guiral, Lanzarote y Sopeña 1991, 106-107 y Gutiérrez 1999, 220, n 920, y, con paralelos más tardíos en Domingo 2006, ${ }^{\circ}$ CEN096, a quien, desde estas líneas, queremos dejar constancia de nuestra gratitud por sus oportunas sugerencias e indicaciones respecto de esta pieza tardoantigua y de sus motivos.
}

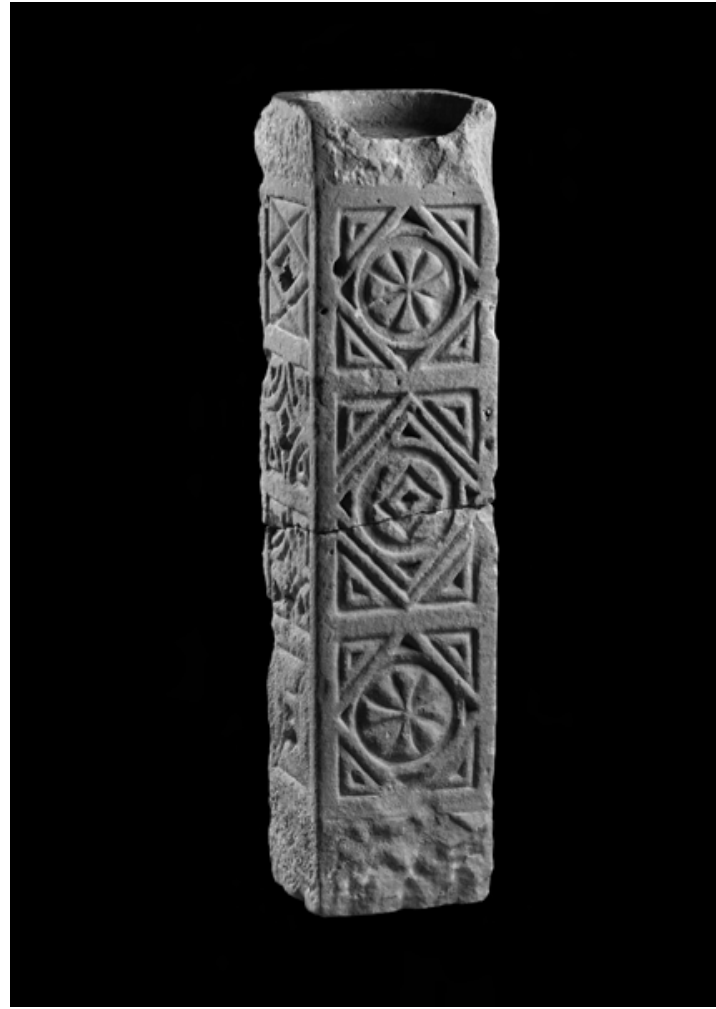

Fig. 23. Pie de altar visigótico procedente de Campo Real/ Fillera hoy en el Depósito Arqueológico del Gobierno de Navarra (Foto cedida por la Fundación para la Conservación del Patrimonio Histórico de Navarra).

cófagos ${ }^{64} \mathrm{y}$ con un hermoso pie de altar visigodo hoy conservado en el Depósito Arqueológico del Gobierno de Navarra (Fig. 2365). Seguramente ya al periodo medieval, deba también ser adscrito un hermoso canecillo con motivo figurado que — procedente del área del Corral del Boticario- se conserva hoy en casa de Dña. Soledad Vera (Fig. 24(b)); un capitel con motivos animales, ya de corte románico, conservado en una colección particular de Sos del Rey Católico (Fig. 25(a)); y —entre otras piezas - hasta seis monumentales pilares de arenisca y una columna recogidos en los campos próximos al despoblado medieval (Fig. 25(b)) y tal vez relacionados con las ruinas de la iglesia — de clara obra altomedievala la que antes aludimos.

\footnotetext{
${ }^{64}$ Escribano y Fatás 2001, 165.

${ }^{65}$ Aunque la pieza fue publicada como procedente de Sangüesa (Uranga e Iñíguez 1971, 56: «de un campo cercano a Sangüesa (...) y muy posiblemente de una 'villa' suburbana»; Buendía 1988, 144 y Poza 2006, 592-594, nº 171) consta en su sigla manual - seguramente del P. Recondo- su procedencia de Fillera, que hemos constatado en el transcurso de los trabajos en que se inscribe esta síntesis.
} 

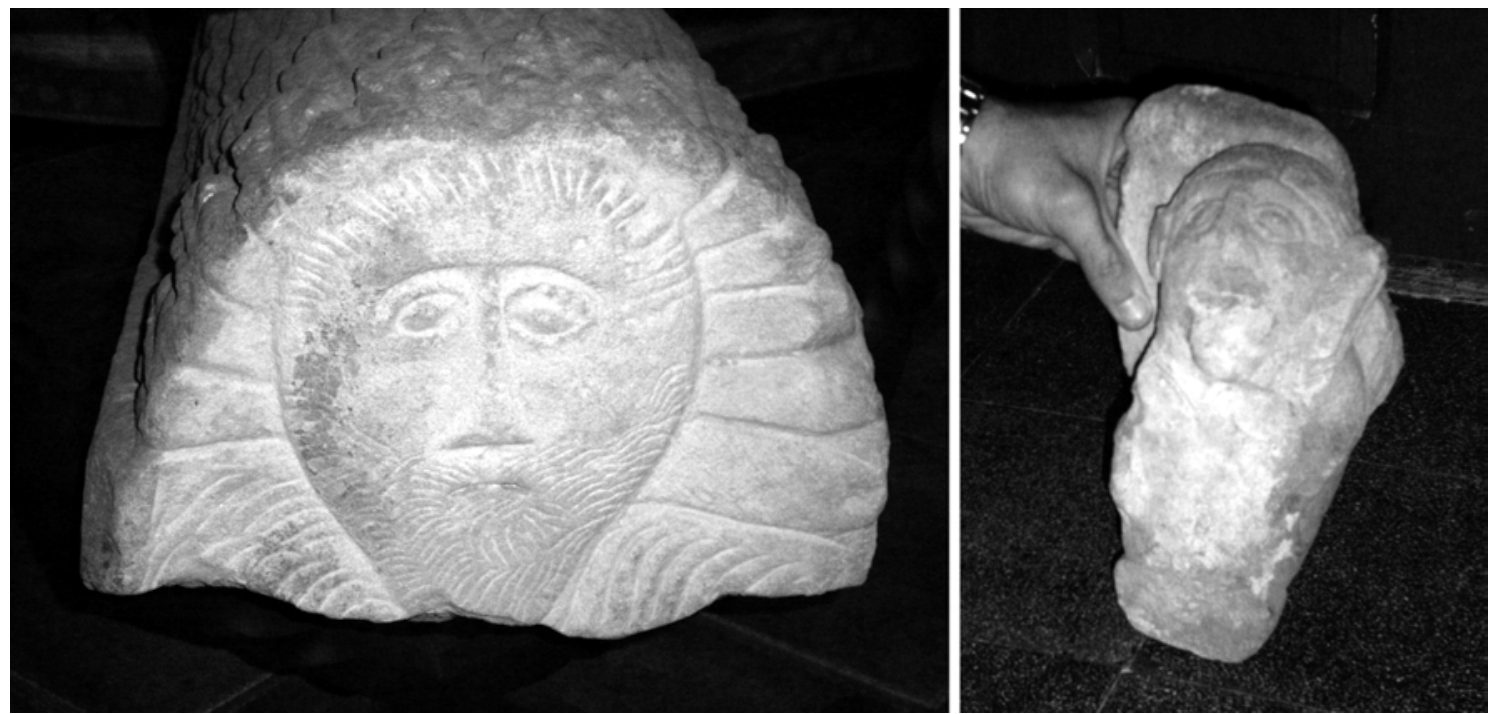

Fig. 24. Pulvinus funerario con relieve antropomorfo y detalles vegetales (a), y canecillo con motivo figurado (b) procedentes de Campo Real/Fillera.
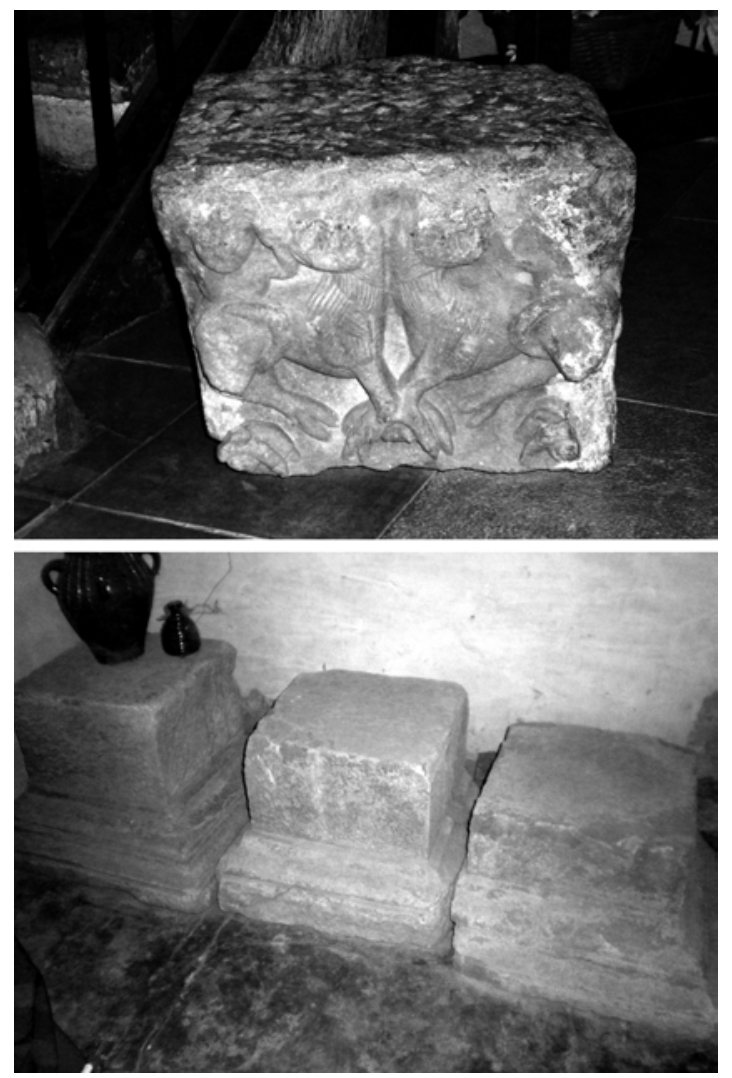

Fig. 25. Capitel medieval con escena figurada de animales (a), y pilares vinculados a la iglesia medieval de Campo Real/ Fillera (b) conservados hoy en propiedad particular en Sos del Rey Católico.

\section{LA EPIGRAFÍA DE CAMPO REAL/FILLERA}

En el conjunto de la riquísima epigrafía romana de las Cinco Villas ${ }^{66}$ es aparentemente poco lo que supone el material epigráfico romano que, con seguridad - y al margen de otras piezas procedentes de la jurisdicción de Sos del Rey Católico pero de las que no se cuenta con una procedencia mejor definida ${ }^{67}$ — ha sido recuperado en el área de Campo Real/Fillera. En concreto, tres epitafios que pasamos a estudiar a continuación (n. ${ }^{\text {ss }} 1-3$, de Val(erius) Fortunatianus, C(aius) Terentius Maternus y Val(erius) Flau[i]anus respec-

${ }^{66}$ Con valoración en Beltrán Lloris 1986(a) y, más reciente en Beltrán Lloris 1997, 314-333.

${ }^{67}$ Concretamente -y dejando a un lado el sensacional lote epigráfico de Sofuentes, pedanía de Sos del Rey Católico (véase nota 4)- un miliario de Valeriano $(E R Z, 42)$, otro de Carino hoy depositado en el Museo de Navarra (Lostal, $1992,142, \mathrm{n}^{\circ} 138=I R M N, 13$ ), otro de Constantino custodiado en idéntica institución (IRMN, 15) (con listado completo y todos los datos en Magallón 1986, 142), la inscripción $E R Z, 46$, traída de la ermita de Nuestra Señora de Serún $(I R M N, 64)$ y la placa funeraria IRMN, 79 así como un conjunto de piezas taurobólicas también conservadas en el Museo de Navarra (IRMN, 80 y 81$)$ y de las que diera noticia Uranga 1966, 226-227, $\mathrm{n}^{\circ} \mathrm{s}$ 1-3 -antes también en Uranga 1926- habiendo vuelto sobre ellas no hace mucho Canto 1997, 33-34. En el transcurso de nuestros trabajos hemos contactado, además, con una cupa anepígrafa que -muy probablemente procedente de Barués, según noticia facilitada por Dña. Mercedes Zorroza, Concejala de Cultura del Ayuntamiento de Sos del Rey Católico- se conserva actualmente en el Museo de Sada y que hemos estudiado de forma monográfica en otro lugar (Andreu, Jordán, Nasarre y Lasuén en prensa, s. pp). 

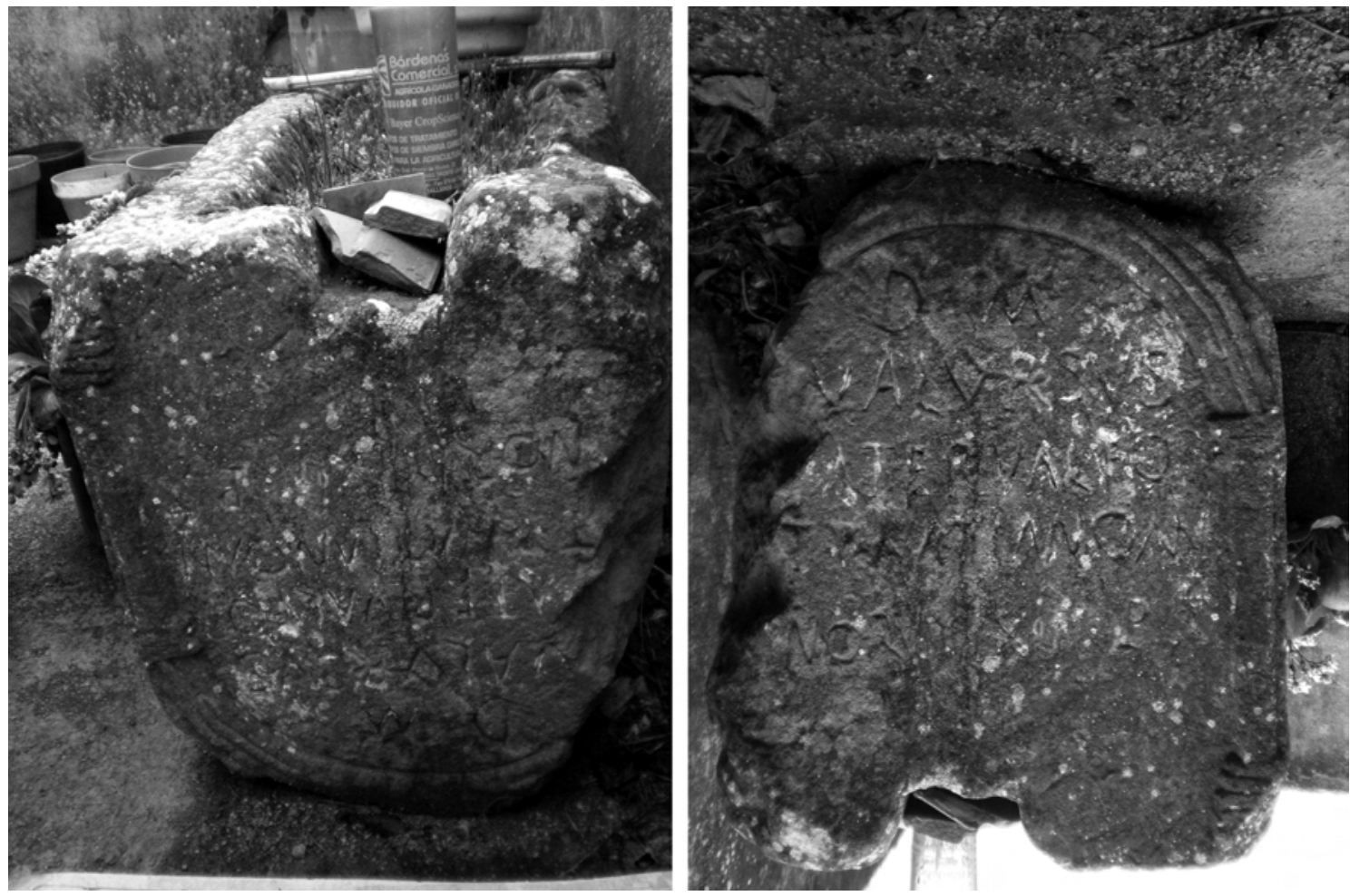

Fig. 26. Cupa funeraria de Val(erius) Fortunatianus conservada en casa de Dña. Isabel Valero, en Sos del Rey Católico y procedente del área del Corral de Mola $(A E, 1977,470)$. Detalle del soporte (a) y campo epigráfico (b).

tivamente) y una cuarta pieza, anepígrafa (n. ${ }^{\circ}$ ), que, sin embargo, nos parece de extraordinario interés al menos en el contexto de la que - muy probablemente y como se ha apuntado más arriba- pudo ser la necrópolis de la ciuitas aquí estudiada.

N. ${ }^{\circ}$ 1.-Cupa funeraria de arenisca (47 x 39 x 77) dañada en su lado izquierdo con fractura que ha afectado ligeramente a la línea segunda del texto y desgaste que recorre el campo epigráfico de arriba abajo. Campo epigráfico (39 x 43) enmarcado por moldura triple a modo de arquillo decorativo apoyado sobre pilastras con decoración vegetal muy gastada y sólo conservado en el lado derecho. La superficie interior está rehundida para el encaje de la urna cineraria. Caracteres capitales rústicas $(4,5-3,5)$ y ausencia de signos de interpunción.

La pieza fue hallada en el transcurso de labores agrícolas junto al Corral de María Mola, a la vez que la estela que estudiaremos a continuación (n. ${ }^{\circ}$ 2) según testimonio de la actual propietaria de la pieza. Hoy se guarda - reutilizada como jardinera e invertida - en el patio de la vivienda de Dña. Isabel Rubio, en Sos del Rey Católico, gracias a cuya ama- bilidad pudimos verla y fotografiarla en la Semana Santa de 2008 (Fig. 26).
$\mathrm{D}$ (iis) $\mathrm{m}$ (anibus)
Val(erius) Vrsus
pater Val(erio) For
tunatiano an
5 noru[m] XIII p(osuit)

\section{3 : aterual, Lostal.}

Lostal 1977, 16-17 (AE, 1977, 470; $A E, 1989,462)$; Lostal 1982, 24; Lostal 1984, 22

Cf.: Beltrán Lloris 1997, 314.

Al margen del extraordinario interés que ofrece el soporte - se trataría, pues, de una nueva cupa que añadir a las ya conocidas para la zona, tanto en el entorno de Sofuentes como en el de Los Bañales de Uncastillo $^{68}$ - y con un aspecto - en fórmula y en decoración - muy semejante al de la que, con alusión a una posible Spes mater, se conserva hoy en el Corral de Bardají de la vecina localidad de Uncastillo, la

\footnotetext{
${ }^{68}$ Al respecto puede verse Andreu, Jordán, Nasarre y Lasuén en prensa, con todos los casos conocidos.
} 

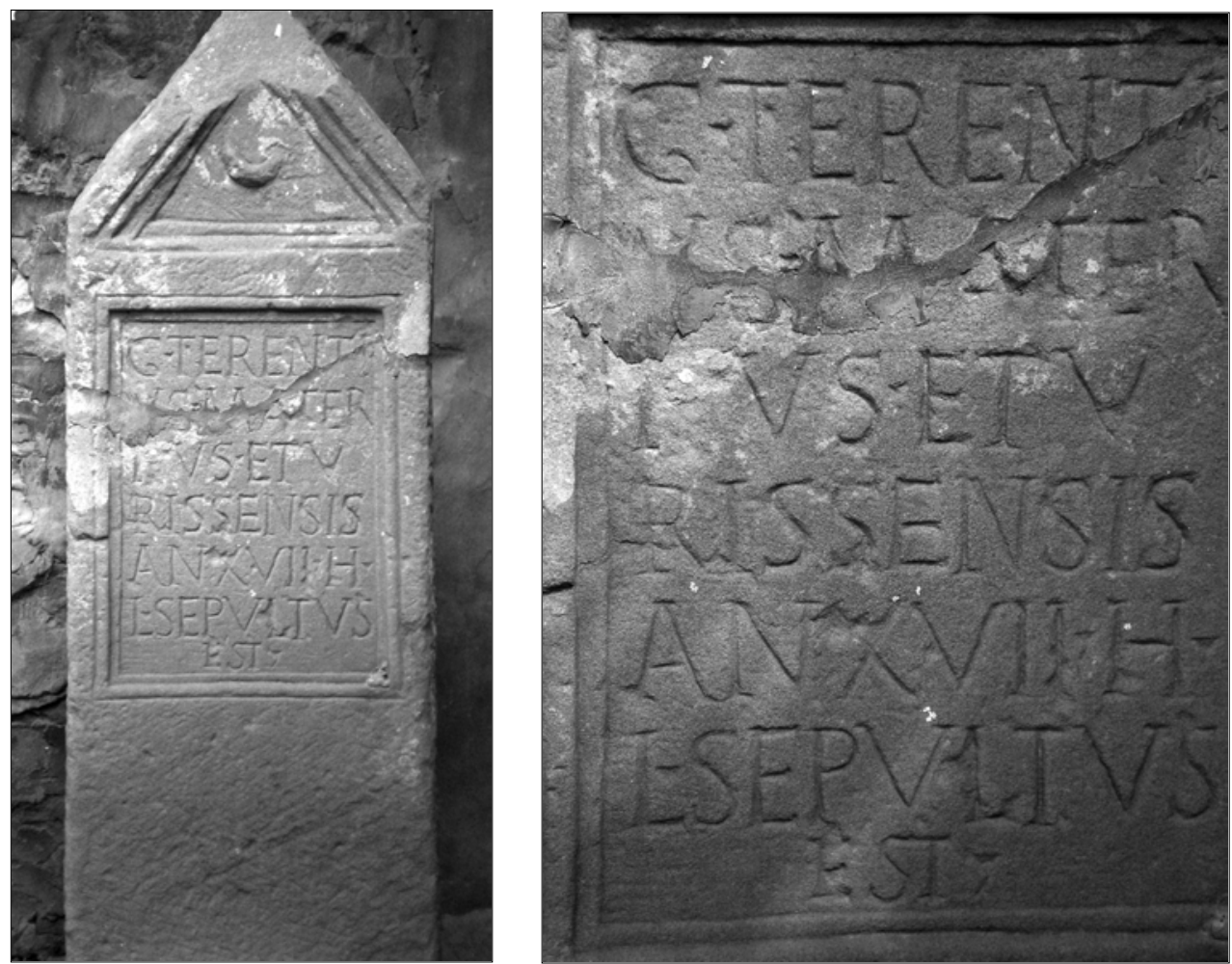

Fig. 27. Estela funeraria de G(aius) Terentius Maternus procedente del Corral de Mola y hoy conservada en propiedad particular en Sos $(A E, 1977,471)$. Pieza completa (a) y campo epigráfico (b).

onomástica que arroja el epitafio ofrece el caso de dos Valerii que, necesariamente, han de conectarse con los otros dos de un segundo documento de Fillera que seguidamente analizaremos (n. 3$)$ y, muy probablemente, con una serie de individuos que, con este gentilicio, se concentran en torno de Santacrís de Eslava (P(ublius) Valeri[us---], Val(erius) Tyrmus y Val(eria) Eraste, y [V]alerius Vrsinus en HEp3, 253; HEp8, 373 e $I R M N, 40$ respectivamente), en la vecina localidad navarra de Rocaforte (Val(eria) Corneliana, en IRMN, 59) y en la zaragozana de Sofuentes (Val(erius) Peculiaris -también en una cupa-, Val(erius) Mar(tialis?) y Val(erius) E(----), en AE, 1977, 483, 484 e IRMN, 62 respectivamente), evidencias que — por su proximidad geográfica - permiten volver a referir a estos Valerii como una de las familias más presentes en la zona ${ }^{69}$ sino también de las más poderosas.

N. ${ }^{\circ}$ 2.-Estela de arenisca $(137 \times 42,5 \times 24)$ con remate triangular decorado con moldura doble y representación de un creciente lunar en relieve. Campo epigráfico $(35,5 \times 48,5)$ enmarcado por moldura

\footnotetext{
${ }^{69}$ Castillo 1997, 131 y Andreu 2006, 202, n. 125.
}

doble y dañado por una fractura que partió la pieza en dos en el momento de su traslado del lugar del hallazgo al de su actual conservación, fractura que fue subsanada con un aplique de cemento que ha afectado sobre todo a la 1. 2. Caracteres capitales cuadradas de excelente factura (5/4,5-3, en 1. 7). Interpunción triangular lanceolada.

Procede del Corral de María Mola, en Fillera. Hoy se guarda en una vivienda particular de Sos del Rey Católico donde — gracias a la espléndida hospitalidad de sus propietarios - pudimos verla y fotografiarla en la Semana de Pascua de 2008 (Fig. 27).

$$
\begin{array}{ll} 
& \text { G(aius) } \cdot \text { Terenti } \\
& \text { us } \cdot \text { Mater } \\
& \text { nus } \cdot \text { Etu } \\
& \text { rissensis } \\
5 & \text { an(norum) XVII } \cdot \mathrm{h}(\text { oc }) \cdot \\
& 1(\text { oco }) \cdot \text { sepultus } \\
& \text { est } \cdot
\end{array}
$$

Lostal 1977, 16-17; (AE, 1977, 471 y $A E, 1989,463)$; Lostal 1982, 25; Lostal 1984, 23 (con foto, fig. 8); Beltrán Lloris 1986 (a), 60 .

Cf.: Beltrán Lloris 1997, 314; Canto 1997, 46; Canto, Iniesta y Ayerra 1998, 69, n. 10; Andreu 2006, 219, n. 236. 
El primer elemento que merece la pena destacar respecto de esta pieza es la presencia de un creciente lunar con los cuernos hacia arriba como motivo decorativo del remate de la misma ${ }^{70}$ especialmente porque éste está atestiguado también en otra cercana inscripción recuperada en la supuesta necrópolis de Los Bañales de Uncastillo $(E R Z, 51)$ y en una segunda procedente de Javier (IRMN, 49) lo que permite atribuir al motivo un cierto predicamento en la documentación epigráfica de la zona. Desde el punto de vista onomástico, a pesar de la origo Eturissensis del difunto - por tanto, relacionable con la Iturissa de Ptolomeo y los Itinerarios ${ }^{71}$ y que, como

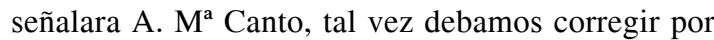
Eturissa $^{72}$ una vez que es ésa la variante que soporta el registro epigráfico- su gentilicio, Terentius —bien atestiguado en Hispania ${ }^{73}$ — , apenas ofrece en la zona un lejano paralelo documentado en un ara de Cirauqui erigida a [L]osa por T[e]rent[i]us Martialis $(A E, 1982,587)$ de igual modo que su cognomen - Maternus - no ofrece demasiados casos dentro del territorio vascón (HEp5, 629, de Olóriz, e IRMN, 43 de Gastiáin, en su versión femenina ${ }^{74}$ ).

N. ${ }^{\circ}$ 3.-Bloque de arenisca ((35) x (46) x 41) partido en su parte superior - con fractura que ha dañado la primera línea del texto-y en el ángulo inferior izquierdo. Caracteres capitales de tipo rústico (4,5-4), sin signos de interpunción y muy desgastados en la parte central de la pieza. En la 1. 4, la $\mathrm{S}$ aparece fuera de la caja de la ordinatio.

Al parecer, y según sus primeros editores, la inscripción procede de Fillera aunque ellos mismos precisan que «no se conservan datos seguros» (Castillo y Bañales 1998, 5) sobre su hallazgo. En 1985, cuando los referidos investigadores de la Universidad de Navarra la fotografiaron, se conservaba en la Casa de Cultura de Sangüesa de donde parece pasó al Convento de los Capuchinos. La hemos buscado en ambos lugares donde, sin embargo, no hemos podido encontrarla. Probablemente se haya perdido.

Val(erio) Flau

[i]ano

Val(erius) Flauus

patri pientis(sim)o

$5 \mathrm{f}($ aciendum $) \mathrm{c}$ (urauit)

\footnotetext{
${ }^{70}$ Marco 1977, 19.

${ }^{71}$ Con todas las fuentes sobre dicha ciudad en Peréx 1986 172-180 y Andreu 2006, 219-220 y con la propuesta de reducción a la localidad navarra de Espinal en Peréx y Unzu 1990.

${ }^{72}$ Canto 1997, 46.

73 Abascal 1994, 227-229.

74 Abascal 1994, 418-420.
}

Castillo y Bañales, 1998, 5-6, $\mathrm{n}^{\circ} 3$ (con foto, fig. 3); HEp 9, 614.

Cf.: Castillo, 1992, 133, nn. 157 y 158; (HEp5, 925; Beltrán Lloris 2002, 631).

Al margen de los comentarios ya antes consignados respecto del gentilicio Valerius y su arraigo en la zona, resulta necesario referir aquí la también notable presencia del cognomen Flauus en algunas piezas del repertorio epigráfico próximo. Así, éste está presente en inscripciones de Barbarin ( $A E, 2002$, 798), Eslava $(A E, 1994,1048)$ o Sofuentes $(A E, 1977$, 479) lo que remite, de nuevo, a un ámbito geográfico —el de las Cinco Villas de Aragón/Navarra Media Oriental— que parece ser el del área de influencia del enclave que aquí estudiamos.

N. ${ }^{\circ}$ 4.-Fragmento lateral izquierdo de una placa de arenisca $(61 \times(65)$ x 22) con tabula ansata moldurada $((58) x 43)$ grabada en su interior y de la que se ha perdido toda el ansa derecha debido a la fractura de la pieza. El soporte, anepígrafo, tal vez pudo contar con un texto pintado hoy, en cualquier caso, perdido.

Procede del lado Oeste del Corral de Mola. Se conserva in situ esperando su incorporación al Museo de Zaragoza, al que informamos de su hallazgo en Febrero de 2008 (Fig. 28).

Pese a su aparente parquedad, varias son las consideraciones que nos sugiere la epigrafía recuperada en el área de Campo Real/Fillera. En primer lugar, la naturaleza funeraria de los textos recogidos unida a la diversidad de sus soportes - no se olvide que dos de ellas (n. ${ }^{\text {os }} 1$ y 2 ) fueron halladas en un área muy reducida- nos ofrece un sugerente escenario para la restitución del paisaje epigráfico de la necrópolis de la ciuitas estudiada. En ella debieron convivir bloques y placas de carácter arquitectónico (n. ${ }^{\text {os }} 3$ y 4) -al servicio de los monumentos funerarios que parecen sancionar los notables hallazgos de material arquitectónico en la zona y el puluinus con retrato funerario arriba aludido (Fig. 24(a)) - con estelas (n. ${ }^{\circ}$ 2) у сupae (n. $\left.{ }^{\circ} 1\right)$, convivencia que, por otra parte, también parece constatarse, por ejemplo, en las vecinas necrópolis de Los Bañales de Uncastillo ${ }^{75}$, Cabezo Ladrero de Sofuentes ${ }^{76}$, o Santacrís de Esla$\mathrm{va}^{77}$. Por otro lado, la presencia de un individuo con mención de origo, el Eturissensis G(aius) Terentius Maternus, parece subrayar, como un elemento más,

\footnotetext{
${ }^{75}$ Andreu y Jordán 2003-2004, 422, y Nasarre y Lasuén en prensa, s. pp.

${ }^{76}$ Beltrán Lloris y Paz 2003, 156.

${ }^{77}$ Mateo, Armendáriz y Sáez de Albéniz 2007, 154 y Velaza 2006, 61.
} 


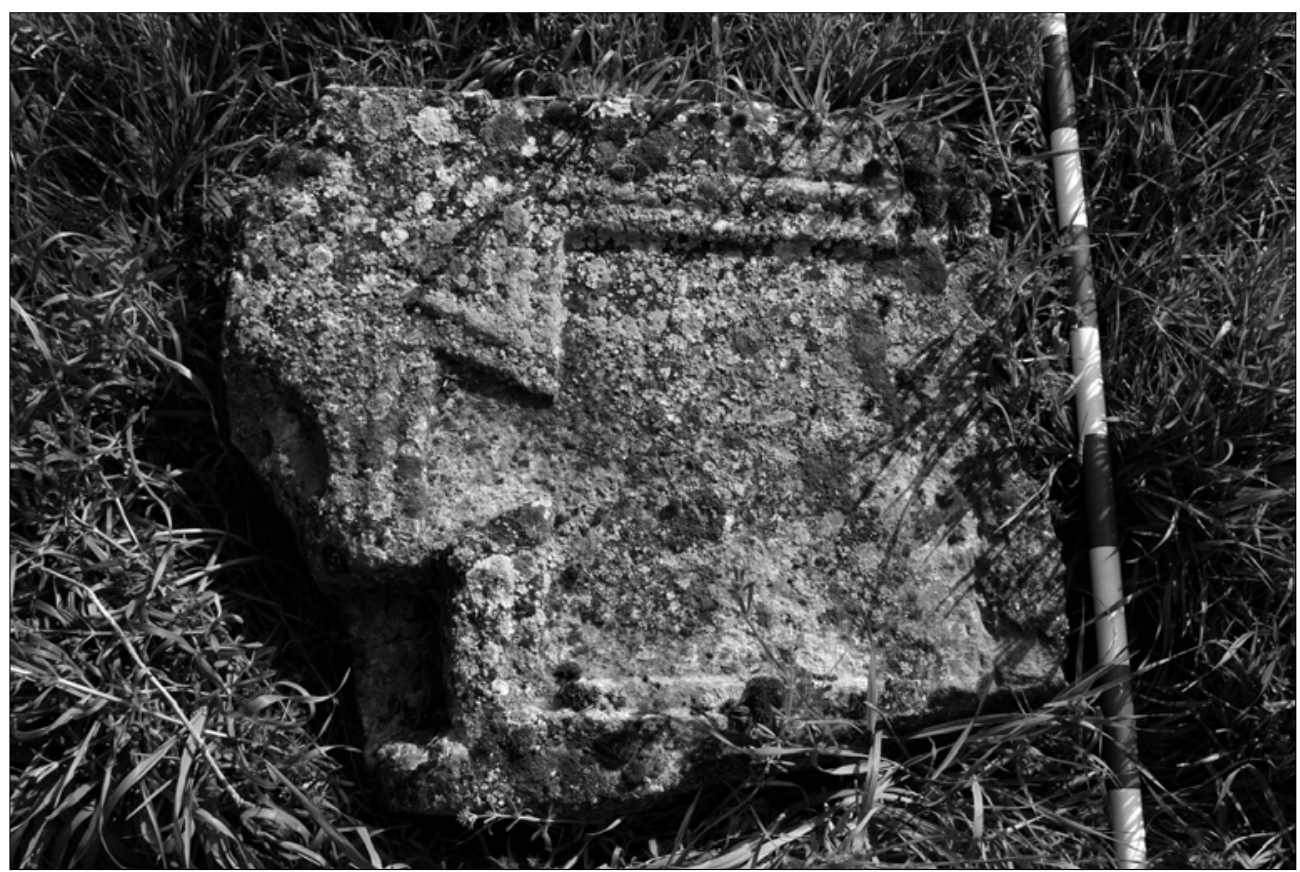

Fig. 28. Fragmento de una tabula ansata anepígrafa conservado in situ en el área del Corral de Mola.

el carácter urbano del enclave pues dicha mención de la ciudadanía de procedencia parece más frecuente en la epigrafía urbana que en la de los territorios rurales $^{78}$, además de ilustrar sobre el atractivo que - del tipo que fuera- ejerció el enclave. Por último, la constatación de una cupa — hasta la fecha la más oriental y septentrional del territorio vascóny el notable protagonismo de los Valerii como grupo familiar también constatado en el área circundante permiten integrar perfectamente el enclave de Campo Real en los patrones de aculturación, poblamiento y sociedad típicos de la zona y que ya en su día fueran descritos por F. Beltrán ${ }^{79}$.

\section{VALORACIÓN FINAL}

La constatación de una nueva ciudad romana en el área nororiental del territorio que las fuentes antiguas atribuyen a los Vascones no nos parece deba considerarse como algo excepcional. Acaso sí por la concentración de enclaves urbanos que ofrece la zona $^{80}$. En cualquier caso, la temprana integración de

\footnotetext{
${ }^{78} \mathrm{Al}$ respecto puede verse Andreu en prensa, s. pp.

${ }^{79}$ Beltrán Lloris 1986(a), 60-73.

${ }^{80}$ Como ya se hizo notar más arriba (véase nota 4 ), en un radio no superior a los 30 kilómetros estarían constatadas, cuando menos, las siguientes comunidades urbanas: Los Ba-
}

toda el área - y de sus comunidades protohistóricasen la órbita de Roma — hacia el 195 a. C. tenemos al ejército romano interviniendo en la ciudad de Iacca y diez años más tarde asediando Corbio, comunidades ambas algo más hacia el Este ${ }^{81}$ pero en cualquier caso no lejanas- y, también, sus muy excelentes posibilidades económicas — perfectamente constatadas por la activa circulación de numerario indígena de cecas bien lejanas en algunos de los oppida protohistóricos de la zona y después debidamente multiplicadas por la red viaria romana-, justifican su tupido poblamiento en época clásica.

Es, precisamente, la estratégica posición del yacimiento la que explica la continuidad de la vida urbana — seguramente redimensionada en cada época: muy notable en época alto-imperial y tardoantigua, igualmente importante en época protohistórica, y menor, en cualquier caso, en su facies ya medievalo, en cualquier caso, del poblamiento en la zona incluso en época tardía, más allá de la incidencia de invasiones cuyo efecto está constatado en lugares bien

ñales de Uncastillo, Santacrís de Eslava y la ciuitas de los Iluberitani de Plinio (Plin., HN. 3, 3, 24), si es que ésta -como vimos- puede reducirse a Lumbier. Pero, seguramente, a ellas debe añadirse el Cabezo Ladrero de Sofuentes que -pendiente de un estudio detallado en su dimensión arqueológica- fue seguramente solar de alguna unidad urbana romana (Fatás 1976, 88 y Beltrán Lloris y Paz 2003, 156).

${ }^{81}$ Liv. 34, 21 y 39, 42. 
próximos $^{82}$ y en línea, además, con lo que sucedió, por ejemplo, en la vecina ciuitas de Los Bañales de Uncastillo que terminó sus días en la forma de extensos fundi como los que documentan los yacimientos de La Sinagoga y La Estanca, en los alrededores de la actual localidad de Sádaba ${ }^{83}$, ambos, en cualquier caso, con raigambre alto-imperial.

La reducción del sitio de Campo Real/Fillera con alguna de las ciuitates citadas en las fuentes debe, en todo caso, considerarse un problema menor máxime cuando otras de las reducciones propuestas para las comunidades atribuidas a los Vascones son sólo probables y cualquier nuevo hallazgo puede modificar el actual estado de $\operatorname{cosas}^{84}$, sin embargo, sí parece lógico que nos detengamos en algunas consideraciones al respecto. Si la Corbio suessetana parece debe buscarse algo más hacia el Gállego ${ }^{85}$ y la Nemanturissa de los listados de Ptolomeo ${ }^{86}$ — aparentemente paralela a Andelo pero algo más al Oeste ${ }^{87}$ - estuvo en Santacrís de Eslava ${ }^{88}$, a la hora de trazar nuevas propuestas de reducción, la investigación —cuando menos- ha de preguntarse por las cecas de acuñación que, normalmente, se vienen adscribiendo al grupo vascón ${ }^{89}$, que operaron en el solar atribuido por las fuentes a esta etnia, o cuyas leyendas, al menos, admiten una base eusquérica ${ }^{90}$ una vez que para el resto de las comunidades vasconas citadas en las fuentes literarias existen tentativas de reducción más o menos sólidas.

En este sentido, la irregular procedencia de la zona de El Sasillo - a apenas tres kilómetros al Oeste del área de Campo Real/Fillera- de un completísimo tesoro de denarios de arsaos casi flor de cuño - por tanto de escasa circulación ${ }^{91}$ — permite — junto con la habitual búsqueda del solar de dicha ceca por la zona Oriental de Navarra y Occidental de Aragón ${ }^{92}$

${ }^{82}$ Al respecto puede verse el caso de la uilla de Liédena, cerca de Lumbier (Taracena 1949(b) y 1950), con valoración en Blázquez 2007.

${ }^{83}$ García y Bellido 1962, Ortiz y Paz 2005 y Escribano y Fatás 2001, 30, 40-41, 80 y 105.

${ }^{84}$ Un estado de la cuestión sobre éstas puede verse en Andreu 2006, y, especialmente, en Ramírez Sádaba 2006, donde se valora también la sugerente propuesta de Canto 1997.

${ }^{85}$ Beltrán Lloris 2001, 74-75.

${ }^{86}$ Ptol. 2, 6, 67.

${ }^{87}$ Ramírez Sádaba 2006, 193.

${ }^{88}$ Mateo, Armendáriz y Sáez de Albéniz 2007, 149.

${ }^{89}$ Sobre esa necesidad de ubicar las cecas pueden verse las reflexiones de Beltrán Lloris 2001, 67-68 y sobre el supuesto grupo vascón de acuñación Heiss 1870,35 y Villaronga 1994, 248 y la valoración al respecto de García-Bellido y Blázquez 2001, 401-402.

90 Beltrán Lloris 2001, 67.

${ }^{91}$ Con todos los datos en Fernández en prensa, s. pp.

92 Con todas las referencias en García-Bellido y Blázquez 2001, 34-35 y en Rubén 2004, 59 además de en Fatás 1976. y junto con la mención a un Arsitanus en una inscripción de Sofuentes (AE, 1977, 476) — aventurar la posible ubicación de dicha comunidad sino en Campo Real/Fillera sí al menos en una zona no muy lejana. Que el citado epígrafe de Sofuentes - que podría fecharse avanzado el siglo I d.C.aluda a una origo Arsitana autoriza a suponer que la antigua ceca indígena devino en época alto-imperial en una comunidad urbana cuyo nombre guardó relación con el del antiguo rótulo monetal. Resulta pues, plausible, pensar que Campo Real/Fillera pueda corresponderse con esta comunidad e incluso que ésta sea la Arsi que, en su peculiar concepción de las etnias y en su particular metodología de atribución geográfica, Ptolomeo alude entre los Edetanos ${ }^{93}$.

Sea como fuere, todo parece indicar que ulteriores trabajos habrán de tomar en cuenta la - a nuestro juicio sólida- documentación de un nuevo enclave urbano en una de las áreas, sin duda, más atractiva del solar que las fuentes antiguas atribuyen a los Vascones. Es deseable que futuras actuaciones arqueológicas en la zona y, desde luego, el sensacional ritmo con el que se están produciendo los hallazgos epigráficos en las áreas limitáneas —en especial en toda la Navarra Media Oriental ${ }^{94}$ — permitan avanzar en la hipótesis de reducción que aquí hemos propuesto y, desde luego, y sobre todo, en la mejor comprensión del papel desempeñado por esta ciuitas en tan interesante área y en tan dilatado arco cronológico. En dicho papel, además de en su evidente desarrollo durante, cuando menos, la época alto-imperial, deberá profundizarse en el estudio de su languidecer tardoantiguo que, a juzgar por parte del material aquí presentado y por la perduración del lugar en la documentación medieval, debió ser también ciertamente notable.

${ }^{93}$ Ptol. 2, 6, 62. Al respecto, puede verse, con toda la bibliografía, García Alonso 2003, 370, autor que también trata la cuestión del método geográfico del alejandrino. Este investigador identifica la comunidad de Arsi con Arse=Saguntum. A nuestro juicio, la ausencia de Arsitani en la epigrafía de Sagunto -pues, desde época temprana la comunidad cívica de Saguntum se auto-denomina Saguntini (CIL, II²/14, 305 o 330), como han comentado también García-Bellido y Blázquez 2001, 37- obliga a revisar esa identificación, razón que nos lleva a cuestionarnos si la Arsi de Ptolomeo no será la arsaos de las monedas y ambas estarán detrás de la mención epigráfica Arsitanus arriba comentada y procedente de un enclave -el del Cabezo Ladrero de Sofuentes- que no dista de Campo Real/Fillera más de 20 kilómetros, y si, además, ambas acaso guardarán relación con la comunidad cívica que -como simple hipótesis de trabajonos parece haber localizado en el yacimiento que ha centrado estas páginas.

${ }^{94}$ Véase al respecto Velaza 2006, 62-68. 


\section{BIBLIOGRAFÍA}

ABASCAL 1994 = J. M. ABASCAL, Los nombres personales en las inscripciones latinas de Hispania, Murcia 1994.

Altadill 1928 = J. Altadill, «De re geographicahistórica. Vías y vestigios romanos en Navarra», Homenaje a D. Carmelo de Echegaray, Pamplona 1928, 465-556.

Andreu (en prensa) = J. Andreu, «Sentimiento y orgullo cívico en Hispania. En torno a las menciones de origo en la Hispania Citerior», Gerión 26-1, s. pp.

Andreu $2006=\mathrm{J}$. Andreu, $«$ Ciudad y territorio en el solar de los Vascones en época romana», J. Andreu (ed.), Navarra en la Antigüedad. Propuesta de Actualización, Pamplona 2006, 179228.

- 2004-2005 = J. ANDREU, «Algunas consideraciones sobre las ciudades romanas del ámbito vascón y su proceso de monumentalización», $\operatorname{ETF}(2)$ 17-18, 251-300.

ANDREu y Jordán 2003-2004 = J. ANDReu y Á. A. JorDÁN, «Epigrafía, ordenación del territorio y poblamiento en territorio de Vascones: Los Bañales de Uncastillo (Zaragoza)», $\operatorname{ETF}(1)$ 16-17, pp. 419-461.

Andreu, Jordán, NASARre y LasuÉn (en prensa) = J. Andreu, Á. A. Jordán, E. Nasarre y M. Lasuén, «Cuatro cupae inéditas en territorio de Vascones (Hispania Citerior)», Aquitania 24, s. pp.

ARIAS $1965=$ G. ARIAS, « ¿Una calzada Jaca-Rioja?», El miliario extravagante 8, 1965, 181-186.

Ariño, Guiral, LanZarote y Sopeña $1991=$ «Capiteles romanos de la Comarca de las Cinco Villas», Saguntum 24, 1991, 97-116.

ArmendÁrIZ 2005 = J. Armendáriz, «Propuesta de identificación del campamento de invierno de Pompeyo en territorio vascón», TAN 18, 2005, 5164.

ArmendáRIZ 2004 = J. ArmendáRIZ, El proceso de formación de las comunidades urbanas en la $\mathrm{Na}$ varra sedimentaria durante el Primer Milenio antes de Jesucristo, Madrid 2004 [Tesis Doctoral Inédita UNED].

Armendáriz y Velaza $2006=\mathrm{J}$. Armendáriz y J. VelazA, «El miliario de Garínoain (Navarra), cruce de caminos en la vía entre Cara (Santacara) y Pompelo (Pamplona)», TAN 19, 2006, 127 145.

BALIL 1960 = A. BALIL, «La defensa de Hispania en el Bajo Imperio», Zephyrus 11, 1960, 179-197.

Beltrán Fortes $2004=$ J. Beltrán Fortes, «Monu- menta sepulcrales en forma de altar con pulvinos de los territorios hispanorromanos: revisión de materiales y estado de la cuestión», AEspA 77, 2004, 101-141.

BELTRÁN LlORIS 2002 = F. BELTRÁN LLORIS, «Epigrafía latina en Aragón (II) (con un apéndice sobre la epigrafía paleohispánica)», Crónica del Aragón Antiguo 1994-1998. De la Prehistoria a la Alta EdadMedia II [Caesaraugusta 75.II], 2002, 593656.

- 2001 = F. Beltrán LlORIs, «Hacia un replanteamiento del mapa cultural y étnico del Norte de Aragón», F. VILLAR y $\mathrm{M}^{\mathrm{a}}$ P. FERNÁNDEZ (eds.), Religión, lengua y cultura prerromanas de Hispania, Salamanca 2001, 69-72.

- 1997 = F. Beltrán Lloris, «Epigrafía Romana», Crónica del Aragón Antiguo. De la Prehistoria a la Alta Edad Media (1987-1993) [Caesaraugusta 72.II], 1998, 275-333.

- 1986(a) = F. BELtrÁn LlORIs, «Epigrafía y Onomástica de las Cinco Villas», Actas de las I Jornadas de Estudios sobre las Cinco Villas (Ejea 1985), Ejea 1986, 53-93.

- 1976 = F. Beltrán Lloris, «El planteamiento urbano de Los Bañales», Symposion de Ciudades Augusteas II, Zaragoza 1976, 153-164.

- 2003 = M. Beltrán Lloris, «Museo de Zaragoza. Crónica de los años 2002-2003», BMZ 17, 2003, 449-618.

- 2000 = M. Beltrán Lloris (coord.), Museo de Zaragoza: 150 años de Historia (1848-1998), Zaragoza 2000.

- 1986(b) = M. Beltrán LloRis, «La Arqueología de las Cinco Villas (síntesis)», Actas de las I Jornadas de Estudios sobre las Cinco Villas (Ejea 1985), Ejea 1986, 19-52.

Beltrán Lloris y PAZ 2003 = M. Beltrán Lloris y J. Á. PAz (coords.), Museo de Zaragoza: guía, Zaragoza 2003.

BLÁZqueZ 2007 = J. M. ${ }^{a}$ Blázquez, «Navarra en la Antigüedad Tardía», en Navarra. Memoria e Imagen. Actas del VI Congreso de Historia de Navarra. III, Pamplona 2007, 51-70.

BlÁZqueZ y MEZQuírIz 1985 = J. M. ${ }^{\mathrm{a}}$ BlázQUEZ y M. ${ }^{\mathrm{a}}$ Á. Mezquíriz, Corpus de Mosaicos de España. Fascículo VII. Mosaicos Romanos de Navarra, Madrid 1985.

BRUN 1986 = J.-P. BRUn, Archéologie du vin et de l'huile en Gaule romaine, Paris 1986.

BuENDía 1988 = J. R. BuEndíA, «Arte», en Navarra, Vitoria 1988, 129-319.

Burillo 1992 = F. Burillo (dir.), Carta Arqueológica de Aragón, Zaragoza 1992. 
- 1989 = F. Burillo (dir.), Carta Arqueológica de Aragón. Inventario Preliminar, Zaragoza 1989.

Canto 1997 = A. M. ${ }^{a}$ CAnto, «La tierra del toro. Ensayo de identificación de ciudades vasconas», AEspA 70, 1997, 31-70.

Canto, Iniesta y Ayerra 1998 = A. M. ${ }^{a}$ Canto, J. InIESTA y J. Ayerra, «Epigrafía funeraria inédita de un área romana inédita: Tafalla y el valle del río Cidacos (Navarra)», CUAUN 6, 1998, 6398.

Castillo $1997=$ C. Castillo, «Onomástica personal en las inscripciones romanas de Navarra», CUAUN 5, 1997, 127-144.

- 1992 = C. CAstillo, «La onomástica en las inscripciones romanas de Navarra», PV Anejos 14, 1992, 117-133.

Castillo y Bañales 1998 = C. Castillo y J. M. ${ }^{\text {a }}$ BAÑALES, «Nuevas Inscripciones Romanas en Navarra», III Congreso General de Historia de Navarra (Pamplona, 20-30 de Septiembre de 1994), Pamplona 1998, 1-15.

CeÁn Bermúdez 1832 = J. A. CeÁn Bermúdez, Sumario de las Antigüedades romanas que hay en España, en especial las pertenecientes a las Bellas Artes, Madrid 1832.

Ceraudo y Piccarreta 2004 = G. Ceraudo y F. PicCARreta, Archeologia Aerea. Studi di Aerotopografia Archeologica, Roma 2004.

Domingo $2006=$ J. A. Domingo, Capiteles tardorromanos y altomedievales de Hispania (ss. IV-VIII d. C.), Tarragona 2006 [Tesis Doctoral inédita URIV].

Enríquez, Fernández, González y LabeAGa 1977 = J. J. Enríquez, J. Fernández, C. González y J. C. LABEAGA, «Datos para la carta arqueológica de la Valdonsella (Zaragoza)», Caesaraugusta 41-42, 1977, 203-246.

EsCALADA 1943 = F. EsCALADA, La Arqueología en la villa y castillo de Javier y sus contornos, Pamplona 1943.

Escribano y FatÁs $2001=\mathrm{M}^{\mathrm{a}}{ }^{\mathrm{a}} \mathrm{V}$. Escribano y G. FAtÁs, La Antigüedad Tardía en Aragón (284714), Zaragoza 2001.

FATÁs 1976 = G. FATÁs, «Para la localización de la ceca de Arsaos», Numisma 138-143, 1976, 85-89.

Fatás y Martín-Bueno 1977 = G. Fatás y M. MarTín-Bueno, Epigrafía romana de Zaragoza y su provincia, Zaragoza 1977.

FERNÁNDEZ (en prensa) = J. FERnÁNDEZ, «Arsaos. Reflexiones históricas y tipológicas en torno a una ceca indígena en territorio vascón», J. ANDREU (ed.), Los Vascones de las fuentes antiguas, Barcelona, s. pp.
Fernández Castro 1982 = C. Fernández Castro, Villas Romanas en España, Madrid 1982.

Fernández-Galiano 1987 = D. Fernández Galiano, Mosaicos romanos del convento jurídico cesaraugustano, Zaragoza 1987.

Galiay 1946 = J. Galiay, La dominación romana en Aragón, Zaragoza 1946.

GAMER 1989 = G. GAMER, Formen Römischer Altäre auf der Hispanischen Halbinsel, Mainz 1989.

García Alonso $2003=$ J. L. García Alonso, La Península Ibérica en la Geografía de Claudio Ptolomeo, Vitoria 2003.

García-Bellido y BlázQuez $2001=$ M. ${ }^{a}$ P. GarcíaBelido y C. BlázQuez, Diccionario de cecas y pueblos hispánicos. Volumen II: Catálogo de cecas y pueblos que acuñan moneda, Madrid 2001.

García yBellido 1962 = A. García y Bellido, «La llamada 'Sinagoga' de Sádaba», BRAH 91, 1962, 13-19.

Gorges 1979 = J. G. GoRgEs, Les villes hispano-romaines. Inventaire et problématique archéologiques, Paris 1979.

Gutiérrez 1996 = M. a Á. Gutiérrez, Capiteles Romanos de la Península Ibérica, Valladolid.

- 1988 = M. a Á. Gutiérrez, «Bases para un estudio del capitel jónico en la Península Ibérica», $B S A A$ 54, 1988, 65-113.

HeIIS 1870 = A. HeIss, Description générale des monnaies antiques de l'Espagne, Paris 1870.

Jimeno JuRío 1966 = J. M. ${ }^{a}$ Jimeno JuRío, «Caminos romanos de Sangüesa a la Solana de Navarra», El miliario extravagante 12, 1966, 310-311.

Labeaga 1987 = J. C. Labeaga, «Carta arqueológica del término municipal de Sangüesa (Navarra)», TAN 6, 1987, 7-106.

LASUÉN y NASARre (en prensa) = M. LASUÉN y E. NASARRE, «Estudio histórico-descriptivo del yacimiento romano de Los Bañales (Uncastillo, Zaragoza)», $\operatorname{ETF}(2)$ 20, en prensa, s. pp.

Lostal 1992 = J. Lostal, Los miliarios de la provincia tarraconense (Conventos Tarraconense, Cesaraugustano, Cluniense y Cartaginense), Zaragoza 1992.

- 1984 = J. Lostal, «Notas sobre la Arqueología Romana de la Valdonsella», Suessetania 6, 1984, 20-24.

- 1982 = J. Lostal, Arqueología del Aragón Romano, Zaragoza 1982.

- 1977 = J. LostaL, «Arqueología del Aragón Romano (primera parte)», Caesaraugusta 41-42, 1977, 5-89.

Magallón 1987 = M. ${ }^{a}$ Á. Magallón, La red viaria romana en Aragón, Zaragoza 1987. 
Magallón $1986=$ M. Á. Magallón, «La red viaria romana en las Cinco Villas», Actas de las I Jornadas de Estudios sobre las Cinco Villas (Ejea 1985), Ejea 1986, 95-157.

Mar y Ruiz de Arbulo 1987 = R. Mar y J. Ruiz de Arbulo, «La basílica de la colonia Tarraco. Una nueva interpretación del llamado Foro Bajo de Tarragona», Los Foros Romanos de las Provincias Occidentales, Madrid 1987, 31-44.

MARCO 1977 = F. MARCO, Las estelas decoradas de los conventos Caesaraugustano y Cluniense, Zaragoza 1977.

Marcos Pous y Castiella 1974 = A. Marcos Pous y A. Castiella, «Prospecciones en Campo Real (límite navarro-aragonés)», Prospecciones Arqueológicas en Navarra 1, Pamplona 1974, 103 136.

Martín-Bueno 1982 = M. Martín-Bueno, Aragón arqueológico: sus rutas, Zaragoza 1982.

- 1980 = M. Martín-Bueno, «Campo Real», Gran Enciclopedia Aragonesa, Zaragoza 1980, 602.

MARURI $2006=$ D. MARURI, «El museo Xaveriano de Javier y su castillo», San Francisco Xavier desde sus tierras de Navarra, Sangüesa 2006, 257. 391.

Mateo, Armendáriz y SÁEz de AlbénIz $2007=$ R. M. ${ }^{\text {a }}$ Mateo, R. Armendáriz y P. SÁez de Albéniz, «La necrópolis de Santa Criz (Eslava)», La tierra te sea leve, Pamplona 2007, 149-155.

Menéndez Pidal 1952 = R. Menéndez Pidal, «El sufijo -en y su difusión en la onomástica hispana», Toponimia, Madrid 1952, 107-129.

Mierse $1999=$ W. E. Mierse, Temples and Towns in Roma Iberia. The Social and Architectural Dynamics of Sanctuary Designs from the Third Century $B C$ to the Third Century AD, Berkeley-London-Los Angeles 1999.

Moret $1776=\mathrm{J}$. de Moret, Investigaciones históricas de las antigüedades del Reino de Navarra, Pamplona 1766.

Navarro, Palao y Magallón 2007 = M. Navarro, J. J. Palao y M. a Á. Magallón (eds.), Villes et territoires dans le bassin du Douro à l'époque romaine, Bordeaux 2007.

NIELSEN 1990 = I. NIELSEN, Thermae et Balnea. The Architecture and Cultural History of Roman Public Baths, Aarhus 1990.

Ortiz y PAz 2005 = M. ${ }^{\text {a }}$ E. Ortiz y J. Á. PAz, Guía de Los Bañales, Atilios, Sinagoga, Zaragoza 2005.

Peréx 1986 = M. ${ }^{a}$ J. Peréx, Los Vascones (el poblamiento en época romana), Pamplona 1986.

Peréx y Unzu 1990 = M. ${ }^{\text {a }}$ J. Peréx y M. Unzu, «Emplazamiento de Iturissa, mansio en la vía de As- torga a Burdeos», La red viaria en la Hispania Romana, Zaragoza 1990, 373-384.

PozA 2006 = M. PozA, «Pie de altar», en La Edad de un Reyno. Las encrucijadas de la Corona y la diócesis de Pamplona, Pamplona 2006, 592594.

RAmírez SÁDABA 2006 = J. L. RAmírez SÁDABA, «Las ciudades vasconas según las fuentes literarias y su evolución en la tardoantigüedad», Espacio y tiempo en la percepción de la Antigüedad Tardía [Antigüedad y Cristianismo 33], Murcia 2006, 185-199.

RAmos 2007 = M. RAmos, «Excavaciones en la ciudad romana de Ilumberis (Lumbier, Navarra)», Caesaraugusta 78, 2007, 521-534.

Rubén 2004 = J. Rubén, Diccionario toponímico y etnográfico de Hispania Antigua, Madrid 2004.

Salinas $2006=$ M. SAlinas, "Campo Real-Fillera (Sos del Rey Católico)», Diccionario Akal de la Antigüedad hispana, Madrid 2006, 196.

STAMPER 2002 = J. W. STAMPER, The Architecture of Roman Temples, Cambridge 2002.

TARACENA $1950=\mathrm{B}$. TARACENA, «La villa romana de Liédena (II)», $P V$ 38-39, 1949, 9-40.

- 1949(a) = B. TARACENA, «Las fortificaciones y la población de la España Romana», Crónica del IV Congreso de Arqueología Española (Elche, 1948), Cartagena 1949, 421-441.

- 1949(b) = B. TARACENA, «La villa romana de Liédena (I)», $P V$ 36, 1949, 353-382.

Tovar y Blázquez 1975 = A. Tovar y J. M. ${ }^{a}$ BlázQUEZ, Historia de la Hispania Romana, Madrid 1975.

Uranga 1966 = J. E. URANGA, «El culto al toro en Navarra y Aragón», en Problemas de la Prehistoria y de la Etnografía Vascas. IV Symposium de Prehistoria Peninsular, Pamplona 1966, 223 231.

- 1926 = J. E. Uranga, «Vestigios del culto al toro en Sos», BCMNa 17, 1926, 415-422.

Uranga e IÑígueZ 1971 = J. E. Uranga y F. IÑígueZ, Arte Medieval Navarro. I. Arte Prerrománico, Pamplona 1971.

VV. AA. 1991 = VV. AA., La casa urbana hispano-romana. Ponencias y comunicaciones, Zaragoza 1991.

VV. AA. 1980 = VV. AA., Atlas de Prehistoria y Arqueología Aragonesas, Zaragoza 1980.

VelazA 2006 = J. VelazA, «Crónica de epigrafía antigua de Navarra (II)», J. Andreu (ed.), Navarra en la Antigüedad. Propuesta de Actualización, Pamplona 2006, 49-68.

Viladés y PAlomar $=\mathrm{J}$. M. ${ }^{\mathrm{a}}$ Viladés y M. ${ }^{\mathrm{a}}$ E. PAlO- 
MAR, «Informe de las prospecciones arqueológicas en los términos municipales de Uncastillo y Sos del Rey Católico, Zaragoza. Campañas 19881993», Arqueología Aragonesa 1993, Zaragoza 1997, 271-279.

Villaronga 1994 = L. Villaronga, Corpus Nummum Hispaniae ante Augusti aetatem, Madrid 1994.
Zarzuelo 2004 = M. Zarzuelo, «Calzadas romanas en las Altas Cinco Villas», Suessetania 22, 2004, 40-67.

Recibido el 05-05-08. Aceptado el 13-07-08. 